\title{
New Records of Sea Level Changes in the Fiji Islands
}

\author{
Nils-Axel Mörner ${ }^{1 *}$ and Pamela Matlack-Klein² \\ ${ }^{1}$ Paleogeophysics \& Geodynamics, Sweden \\ ${ }^{2}$ The Portuguese Sea Level Project, USA
}

Submission: October 29, 2017; Published: December 20, 2017

*Corresponding author: Nils-Axel Mörner, Paleogeophysics \& Geodynamics, Rösundavägen 17, 13336 Saltsjöbaden, Sweden, Tel: +46 87171867;

Email: morner@pog.nu

\begin{abstract}
New sea level records from the Yasawa Islands in Fiji are presented. Beachrock occurs frequently on the beaches in the zone between mean and high tide levels on most of the islands. They date to the last 4200 years. The present sea level has produced distinct shore marks in the form of under-cut notches, rock-cut platforms and sea-caves in the bedrock, as well as sand accumulations with a clear mean high tide level (HTL). The fieldwork was concentrated in 10 sites. Elevation was measured with a high-precision instrument with respect to HTL. Ages were determined by 17 C14-dates. A $+70 \mathrm{~cm}$ higher sea level was observed, sampled and dated at AD 1530-1673. It was followed by a significant regression of about 1.7-1.8m, killing coral reefs and cutting a new rock-cut platform some $20-30 \mathrm{~cm}$ above present mean low tide level (LTL). Then sea level rose again to its present position, or slightly above, a level, which remained fairly constant over the last 150 200 years. In the last 60 years corals were killed due to a sea level lowering or a severe bleaching episode. After that very stable sea level conditions must have prevailed for the last decades, forcing corals at several sites to grow laterally into microatolls.
\end{abstract}

Keywords: Relative sea level changes; Regional eustasy; Rotational eustasy; Yasawa Islands; Fiji

\section{Introduction}

Before addressing our research project, it seems appropriate to review the regional background with respect to plate tectonics, regional geography, the interaction of changes in land and sea levels, and especially previous research achievements in Fiji with respect to sea level changes. It seems surprising to note that all previous work has been addressed to interglacial and Holocene sea level change older than the last millennium, because it is the sea level of the last 500-1000 years that have the potential to act as a key to our understanding of what is actually going in present time.

\section{Plate tectonic setting}

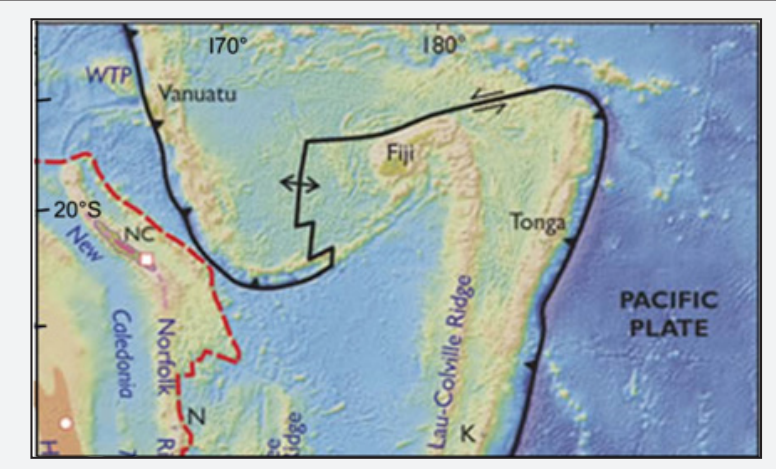

Figure 1: The tectonic setting of Fiji with respect to predominant plate tectonic structures (based on [4]).

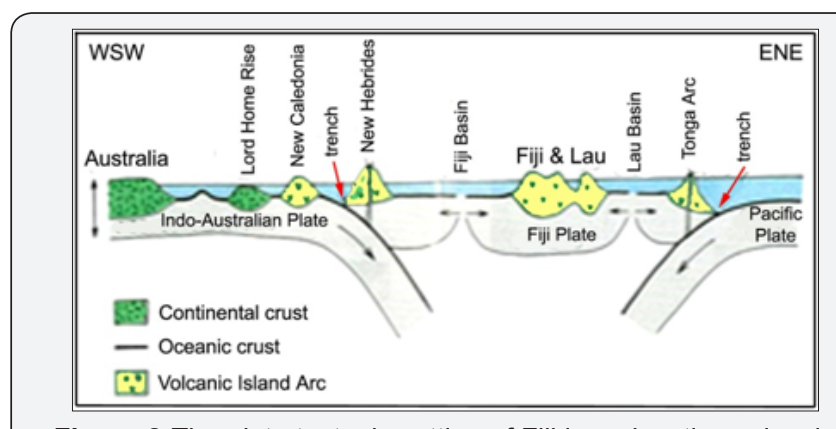

Figure 2:The plate tectonic setting of Fiji is an inactive volcanic island arc formation (based on [1]). The seismic activity is quite high, however [3].

Fiji is positioned between plates of complex geodynamic force and motion (Figure 1). According to the Fijian Ministry of Land and Mineral Resources [1], the Lau-Colville Ridge and Fiji represent an old dormant island arc ridge (Figure 2). However, this area is still seismically active [2-4]. For example, Suva experienced a M 6.8 earthquake in 1953 and a M 7.1 earthquake in 2009. In the Yasawa Islands area, the subject of this paper, a M 6.8 earthquake occurred in 1902 and a M 6.1 earthquake in 1984 [2].

\section{Geography of the Fiji Islands}

The nation of Fiji consists of about 330 separate islands (Figure 3). The main island is Viti Levu with Vanua Levu the 
second largest. The sea level changes and archaeology of Viti Levu have been studied by $[5,6]$. The eastern island group known as the Vanuabalavu Islands have been investigated by [7]. Kadavu Island has been studied by [8]. The Yasawa Islands were the target of our own investigations with respect to sea level changes. The Mamanuca Islands have been studied by $[9,10]$.

\section{Changes in land and sea levels}

The tide-gauges at Lautoka and Suva on Viti Levu (Figure 3) provide records of the relative sea level changes since 1992 and 1972, respectively. In the vicinity of the tide-gauge stations there are GPS stations measuring the changes in crustal level. Both tide-gauge stations seem very unfortunately placed on heavy harbour constructions resting on soft marine sediments susceptible to significant compaction, and can hardly be used to decipher the present trend of sea level changes [11].

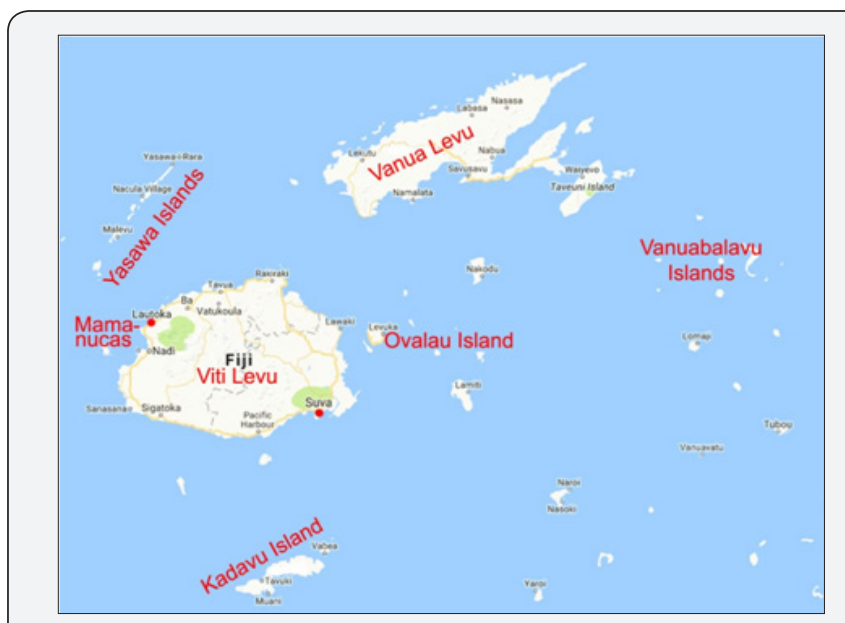

Figure 3: Geographic setting of the Fiji Islands. The present paper will provide new material with respect to sea level changes and the coastal evolution of the Yasawa Islands. Red dots at Suva and Lautoka refer to the sites of tide-gauge stations and GPS-stations [11].

Several authors have tried to apply a seismotectonic zonation of the Fiji Islands (e.g. [12-16]). According to [16] only the Ovalau-Moturiki Islands (just east of Viti Levu) represent stable tectonic conditions, however.

\section{Previous sea level research}

As far as we know, there have been no studies of sea level changes conducted in the Yasawa Islands, except for a few notes (e.g. [14]). In this case our investigation brings forward new material. On Viti Levu, the Ovalau-Moturiki Islands, the Vanuabalavu Islands, the Karavu Island and the Mamanucas Islands, there are previous investigations to consider. Before addressing those papers, there are a few general problems to consider.

Radiocarbon dates of marine material need to be calibrated with the so-called reservoir effect satisfactorily well determined. Petchey et al. [17] reports the ages of four modern shell and coral samples. The reservoir ages were around 450 years, a value we adopted and used as $450 \pm 30$ years in our marine radiocarbon calibration via OxCalv4.2.4 [18]. This makes direct comparisons complicated as, for example, [5] used a reservoir value of 370 years and an old calibration curve [19], and [7] used 438 years and an older calibration technique [20].

The use of datum level is another subject of great difference. Both $[5,7]$ use the lowest astronomical tide (LAT) as their zerolevel. This is quite surprising as this level is a theoretic level $[21,22]$ not recognizable in the field. The unfortunate choice of LAT as their zero-level generates problems with respect to the identification of past sea level index points.

Past sea level data can only be referred to MSL (usually more or less arbitrary, however), HTL (morphological features like notches, sea caves, rock-cut platforms and some beach structures) or LTL (microatolls). This implies that sea level graphs with a datum set at LAT become misleading as they show data points above the chosen LAT-datum, which in fact may not represent any higher sea level position.

It seems natural that the nautical charts are referenced to the low-tide level. But geological and biological associations to shore structures, corals in situ or marine shells and corals in shore deposits are all much better related to the high-tide level, which in most cases is very easily identifiable. Therefore the HTL was selected as the ideal datum. The mean-tide level is usually also easy to identify on a beach, as a minor break in slope and concentration of larger particles like coarse sand and gravel [23].

The present tidal range is given as $1.30 \mathrm{~m}$ by NOAA [21] and maximum 1.84 for Suva and 1.82 for Nadi according to [24]. In the field, a tidal range of $1.51 \mathrm{~m}$ was measured. The conversion to LAT is not obvious (and we have no information of what value previous authors have used), but it seems that LTL should be about $+30 \mathrm{~cm}$, MTL about $+100 \mathrm{~cm}$ and HTL about $+170 \mathrm{~cm}$ with respect to the LAT-datum [25].

Finally, it is interesting to note that all the previous papers are devoted to Mid and Late Holocene sea level data, and that there is a general lack of data for the last millennium. This is why the study, being focused on the last 500-600 years' field evidence on sea level changes, will fill a gap in the sea level history of the Fiji Islands [26-27].

Viti Levu: Nunn \& Peltier [16] listed 32 C14-dated samples from 11 sites on Viti Levu. Additional dates come from [9,28,29], and our dates from Maui Bay (below). The data are plotted in Figure 4.

From Rove Peninsula (SW Viti Levu), [28,29] have reposted a stratigraphical record spanning the entire Holocene. At around 8000 cal.yrs BP marine influence is recorded at the $-3 \mathrm{~m}$ (MSL) level. At $8000 \mathrm{BP}$, global eustatic sea level was at about $-10 \mathrm{~m}$ [30], suggesting that the Rove Peninsula has been uplifted by about $7 \mathrm{~m}$ since $8000 \mathrm{BP}$; i.e. at a mean rate of $0.875 \mathrm{~mm} / \mathrm{yr}$. Therefore, there are good reasons to dismiss their maximum sea level of about $+2.1 \mathrm{~m}$ dated $4055 \pm 575$ cal.yrs BP (suggesting a mean uplift of $0.525 \mathrm{~mm} / \mathrm{yr}$ ). 
From Vuda Point, between Nadi \& Lautoka, [9] describes microatolls of Porites sp. at $16 \mathrm{~cm}$ below MTL dated at $6460 \pm 70$ and $6350 \pm 60 \mathrm{cal} . y r s \mathrm{BP}$, which corresponds to a sea level position at about $+0.8-1.0 \mathrm{~m}$. If eustatic sea level at that time was at about $-2.0 \mathrm{~m}$, the Vuda Point area is likely to have gone up by $2.0 \mathrm{~m}$; i.e., at a mean rate of $0.312 \mathrm{~mm} / \mathrm{yr}$.

Bloom [31] reports the finding of a submarine peat-bed in a drowned valley tributary to the Rewa River east of Suva dated at a depth of $-4.5 \mathrm{~m}$ with a C14-age of $5500 \pm 110 \mathrm{BP}$, corresponding to $6295 \pm 111$ cal.yrs BP. If we assume a eustatic position at that time of about $-1.5 \mathrm{~m}$, the site would have gone down by $3.0 \mathrm{~m}$ or at a mean rate of $0.476 \mathrm{~mm} / \mathrm{yr}$, which seems reasonable for a delta area. Wood at $-0.2 \mathrm{~m}$ in the Rewa River delta has been dated at $4165 \pm 245$ cal.yrs BP. Even this date is likely to represent subsidence, and has therefore been ignored in the sea level graph of Figure 4.

Obviously, there must be differential tectonics involved; uplift of Rove Point, uplift of Vuda Point and subsidence of the Rewa River delta. All the other sites seem to provide a reasonably congruent picture (i.e. stability); viz. sea level at about $+0.3 \mathrm{~m}$ from 5600 to 4900 cal.yrs BP, at about $\pm 0.0 \mathrm{~m} 4150$-3950cal.yrs $\mathrm{BP}$, at about $+0.3 \mathrm{~m}$ around 3350 cal.yrs BP and at about $-0.5 \mathrm{~m}$ from 2900 to 1500cal.yrs BP (as illustrated in Figure 4).

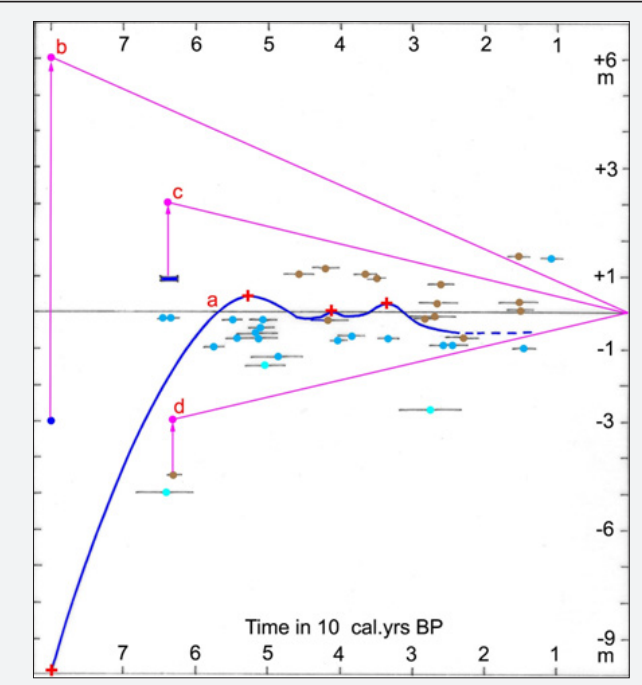

Figure 4: Sea level records from Viti Levu with respect to present mean sea level: brown dots = peat and wood denoting land level samples, blue dots $=$ corals (darker) and shells (lighter) denoting marine samples. (a) the sea level curve inferred from the data points, (b) the $7 \mathrm{~m}$ uplift of the Rove Peninsula, (c) the $2 \mathrm{~m}$ uplift of the Vuda Point, and (d) the $3 \mathrm{~m}$ subsidence of the Rewa Delta (also affecting the $-0.2 \mathrm{~m}$ wood sample of about 4200 cal.yrs BP).

Ash [5] investigated three sites along the northeast coast of Viti Levu and had 7 samples radiocarbon dated. He concluded that sea level rose to about $+0.45 \mathrm{~m}$ by $5300 \mathrm{BP}$ and "has since declined at a constant rate". He also claimed: "sea level has not been significantly raised since $1630 \pm 250$ years BP". The last statement is seriously contradicted by the present findings in the Yasawa Islands, however (below).
The earliest inhabitants of the Fiji Islands were the Lapita people. Kumar et al. [6] reported the finding of charcoal dated at $2583 \pm 233$ cal. BP. Nunn [32] gives an age of the Lapita settlement of "approximately 1350-750BC" (i.e., 3300-2700BP). This is in good agreement with the general Lapita immigration according to [33] and the stratigraphic records from Tavua Island, west of Nadi, by [10].

We investigated a section at Maui Bay on the south-coast including a piece of pottery and shells dated at $4019 \pm 103 \mathrm{cal}$. yrs BP (below), suggesting that people might have been present significantly earlier, however.

The Ovalau-Moturiki Islands: The Ovalau Island lies just east of Vitu Levi with Moturiki Island close by. They were studied by [34]. According to [34] the islands "have been subsiding very slowly for most of the past few thousand years". According to [16], however, these islands represent stable tectonic conditions, and would hence record regional eustatic changes in sea level.

There are 10 C14-dates from Ovalau Island and 7 from Moturiki Island [16]. When plotted against time, the data suggest that sea level was at around $+0.5 \mathrm{~m}$ (MSL) in the period 6500-4500cal.yrs BP and at about +0.4 to $+0.7 \mathrm{~m}$ (MSL) in the period 3500-2900cal.yrs BP. Two dates from $+1.6 \mathrm{~m}$ (LAT) of about 5700 cal.yrs BP and from $+1.5 \mathrm{~m}$ (LAT) of about $3700 \mathrm{cal}$. yrs BP are problematic [34].

The Vanuabalavu Islands: Nunn et al. [7] undertook an extensive survey of past Holocene and Pleistocene sea levels as recorded by shore notches and marine deposits. The story is backed up by 4 C14-dates of Holocene deposits (below recalibrated according to the methods used) and $3 \mathrm{Th} / \mathrm{U}$-dates of Last Interglacial material. As mentioned before, they use a theoretical LAT as their zero-datum, which poses problems with respect to the identification of morphological sea level criteria, according to [7] here "typically marked by shore platforms, notches, marine caves and, less commonly, fossil corals and beach deposits". In the text they often talk about elevation with respect to "its modern analogue" (which is to be recommended) and some drawings give elevation with respect to mean sea level (which implies a new zero level about $70 \mathrm{~cm}$ above LAT).

Nunn et al. [7] observed 3 different shorelines in the Vanuabalavu Islands; an upper $+9-10 \mathrm{~m}$ level of unknown Pleistocene age, a $+5 \mathrm{~m}$ Last Interglacial Level, and a $+1-2 \mathrm{~m}$ Holocene level. Their records have been combined into a shoreline diagram in Figure 5, and supplied with some additional information. The Last Interglacial level (red) seems to go through all sites at a fairly uniform level of about $+5 \mathrm{~m}$ above MTL. The Holocene level (blue) is by no means uniform, varying between around $+1 \mathrm{~m}$ and $+2 \mathrm{~m}$. Because of the uniform Last Interglacial level, the Holocene irregularities cannot be interpreted in terms of differential tectonics, but have to be from field interpretation; the $+2-3 \mathrm{~m}$ levels on Mago Island are far from clear, on Kaibu Island there are no such levels recorded, on Yacata Island the $+2-3 \mathrm{~m}$ levels are unclear, and this is also the case with the $+2 \mathrm{~m}$ 
level of Vatuvara Island. Much better and more conclusive are the $+1 \mathrm{~m}$ levels of Vanuabalavu and Namalata Islands. The data presented suggest an elevation of $+0.9 \mathrm{~m}$ to $+1.3 \mathrm{~m}$ and an age of $3540 \pm 170$ cal.yrs BP to $3959 \pm 180$ cal. BP (overlapping at $3745 \pm 69$ years). Therefore, $a+1.1 \pm 0.2 \mathrm{~m}$ level with an age of about 3750 cal.yrs. BP is proposed. The microatoll (Porites) at $+0.2 \mathrm{~m}$ on Avea Island is indicative of sea level stability around $4178 \pm 180$ cal.yrs BP at about $+0.6 \mathrm{~m}$.

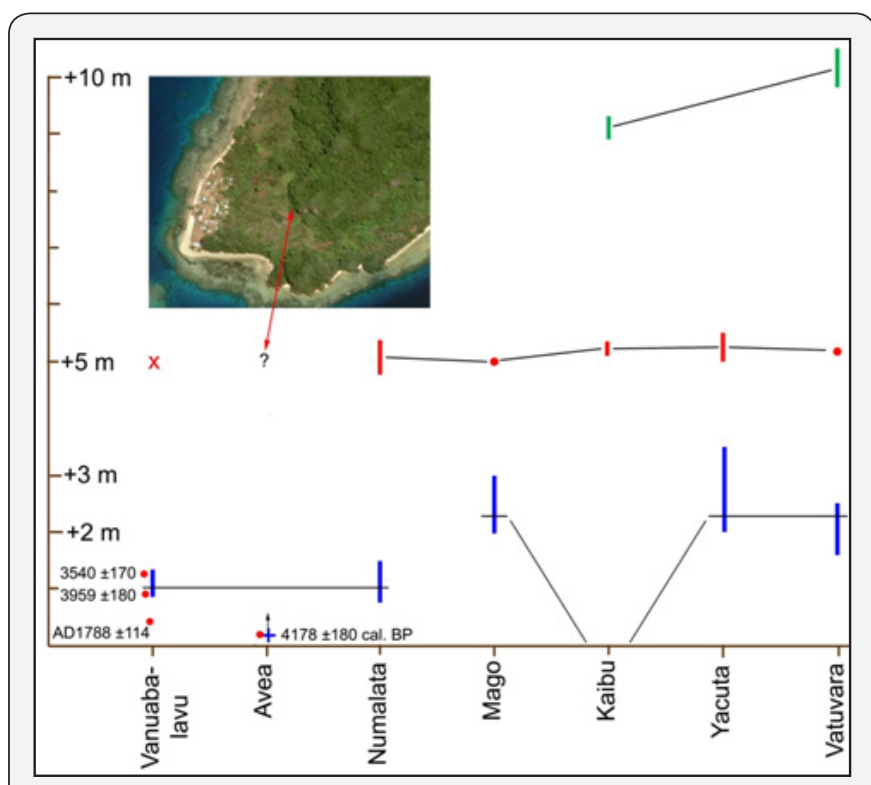

Figure 5: Shoreline diagram for the Vanuabalavu Islands based on material presented by [7] and our interpretations and additions. Inserted Google image shows that there is a distinct inland shoreline, here proposed to represent the $+5 \mathrm{~m}$ Last Interglacial level. The Late Holocene sea level maximum is preferably placed at about $+1 \mathrm{~m}$ (left 3 sites).

On the south tip of the Vanuabalavu Island, there is a big cave named the Qaranilaca Cave. Its floor is given as "approximately 2.1-2.5m above mean low-water spring tide" [35]. This datum is not very useful, but corresponds to $0.8-1.2 \mathrm{~m}$ above HTL and $1.5-1.8 \mathrm{~m}$ above MTL. The stratigraphy is interesting [7,35,36]. The top $70 \mathrm{~cm}$ is a bed indicating human habitation. According to Nunn et al. [7], it represents a significant regression at about 300BP (AD 1788 $\pm 114 \mathrm{cal}$. yrs). Then follows a $7 \mathrm{~cm}$ marine bed (with sharp boundaries below and above) at $+0.25-0.30 \mathrm{~cm}$ above HTL. Below that are two beds with human habitation material dated at AD cal. 660 to 1160 . At the base, $50 \mathrm{~cm}$ below HTL and $10 \mathrm{~cm}$ above MTL, there is a second marine bed of sand and beachrock.

Kadavu Island: Nunn \& Omura [8] studied the Quaternary sea level changes on Kadavu Island. Their tectonic interpretation seems hardly tenable. The structural observations, on the other hand, seem quite straightforward; a "reef limestone" reaching $+7.1 \mathrm{~m}$ and dated to the Penultima Interglacial around 210Ka BP ( $3 \mathrm{Th} / \mathrm{U}$-dates given), an undated "predominant erosional bench" at $+2.6-3.4 \mathrm{~m}$ of assumed Last Interglacial age, and an absence of emerged Holocene levels. This is illustrated in Figure 6.

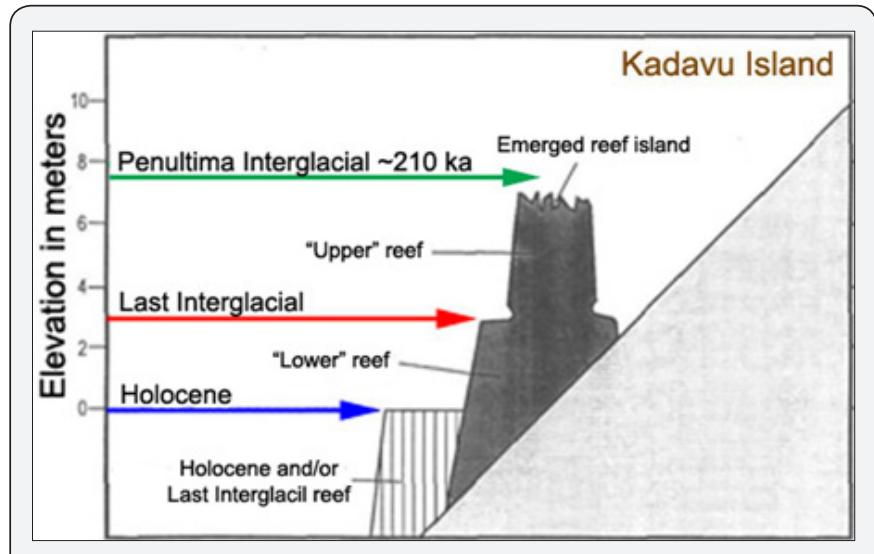

Figure 6 : Sea level on Kadavu Island based on data from [8].

There is a clear difference in elevation of the three shorelines in Figure 4 (Vanuabalavu) and Figure 6 (Kadavu): The Penultima Interglacial level of $+7.5-8.0 \mathrm{~m}$ on Kadavu seems to correspond to the $+9-10 \mathrm{~m}$ shoreline (green) on Vanuabalavu, The Last Interglacial level at $+3 \mathrm{~m}$ corresponds to the $+5 \mathrm{~m}$ level in Vanuabalavu (red), and the absence of emerged Holocene levels on Kadavu correspond to the $+1 \mathrm{~m}$ level in Vanabalavu (blue). A Penultima Interglacial sea level at $+7.5 \mathrm{~m}$ calls for some tectonic uplift. At the same time, however, the Last Interglacial and Holocene sea levels are indicative of predominant stability. Therefore, it seems to represent an episodic uplift of at least $5 \mathrm{~m}$ in pre-Last Interglacial time.

Mamanucas Islands: Morrison et al. [10], studied nine cay islands of the Mamanucas Islands, located between Vita Levu and the Yasawa Islands. Cay islands are small sandy islands of low elevation formed on top of coral reefs by the erosional debris of corals, mixed with other marine organisms. They reported C14-ages from 3 cay sand islands. The subsurface ages go back to about 2200 cal.yrs BP. All the surface dates belong to the last 600 years. The study has little to contribute to sea level changes. It just supports the notion that sea level had changed from a general rise to a general stability (or fall as proposed by [16]) well before 2200BP.

Morrison et al. [10] studied Tuvua Island in the same island group with respect to sediment stratigraphy and archaeological material. Coral fragments without morphological relation to any beach structure were dated; one at $+1.9 \mathrm{~m}$ (MSL) at $2816 \pm 20 \mathrm{BP}$ and one at 1.75 (MSL) at $3294 \pm 21 \mathrm{BP}$, suggesting that sea level was at about the present level, or even somewhat higher. The archaeological remains have ages in full agreement with the age of Lapita immigration according to [32].

\section{Methods}

Before going to Fiji, we carefully scanned suitable coastal segments of the Yasawa Islands as recorded on Google Earth images. After that we selected our spots and formulated our fieldwork program. Sometimes, this was not easy because we were not sure how to arrange local transport. In the field, we 
investigated the morphological characteristics and decided about how to work with respect to levelling, photo documentation and sampling for C14-dating.

We used the mean high-tide level (HTL) as our datum because it was morphologically easily identified. This level is about $70 \mathrm{~cm}$ above mean-tide level (MTL) or mean sea level (MSL), and about $170 \mathrm{~m}$ above the lowest astronomical tidal level (LAT). Levelling was performed with a high-precision Kern instrument, implying a measurement accuracy of better than $1.0 \mathrm{~cm}$. Microatolls were observed and their upper top surface was measured with respect to the sea level at low tide to the minute of its lowest position. The photo documentation includes several hundreds of images taken by different cameras, including one under-water camera.

Radiocarbon AMS dates were performed by Professor Göran Possnert at the Ångström Laboratory at Uppsala University. The marine calibration was done according to OxCal v4.2.4, with a reservoir effect of $450 \pm 30$ years applied [36].

\section{Results from Fiji Island}

Because the Fiji Islands were going to be the center piece at the UN conference in June 2017 [37] and at the COP23 conference in Bonn in November 2017 [38], there suddenly became an urgent need of a careful sea level investigation in Fiji with respect to present trends and recent to sub-recent changes in sea level. Therefore, we initiated a new sea level project in the Fiji [26]. After studies of coastal segments on Google Earth, we selected the Yasawa Islands as our main target.

Our field studies spanned 3 weeks in March 2017. The locations of our investigation sites are shown in Figure 7, and include four sites on Viti Levu (coastal observations at Denarau west of Nadi and at Maui Bay east of Sigatoka, and the locations of the tide-gauge stations Lautoka and Suva). However, our main investigation concentrated on 10 sites in the Yasawa Islands.

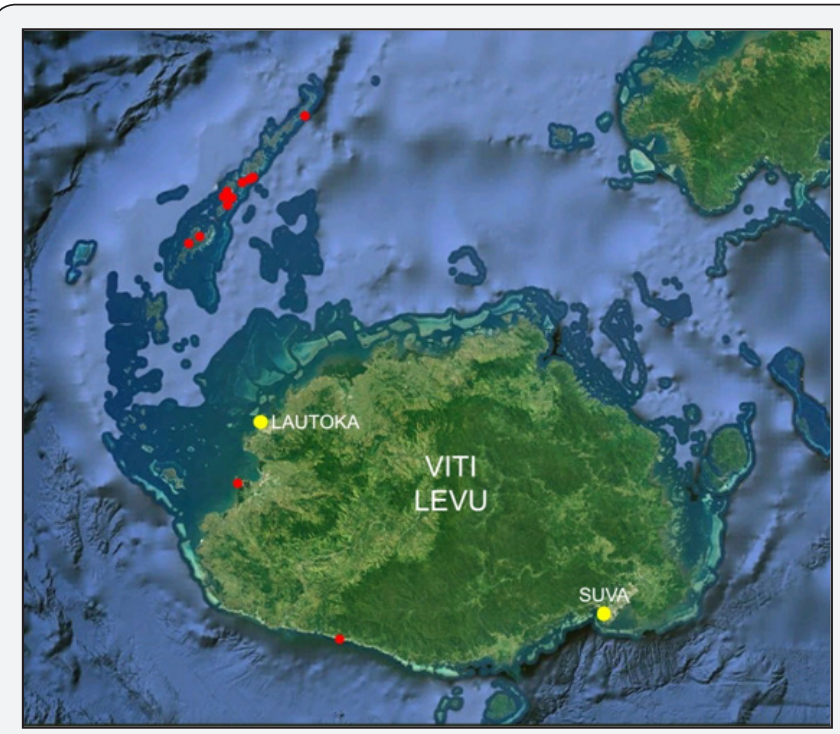

Figure 7 : The investigation sites (red dots) at Viti Levu and the Yasawa Islands.

\section{Studies on Viti Levu}

The investigations on Viti Levu will be described as shorter notes under this section. The main report on our results from the Yasawa Islands will follow below.

\section{The Lautoka and Suva tide-gauge stations}

The study of the two tide-gauge stations at Lautoka and Suva has already been reported on [11]. Our main conclusion was: "Any application of mean trends would produce meaningless values rather misguiding than assisting in the handling of estimation of on-going absolute sea level changes".

This is important, and implies that we must seek other means of establishing the present trend in regional ocean level changes. Consequently, this was our main target in our fieldwork in the Yasawa Islands, besides recording sub-recent to Late Holocene sea level changes.

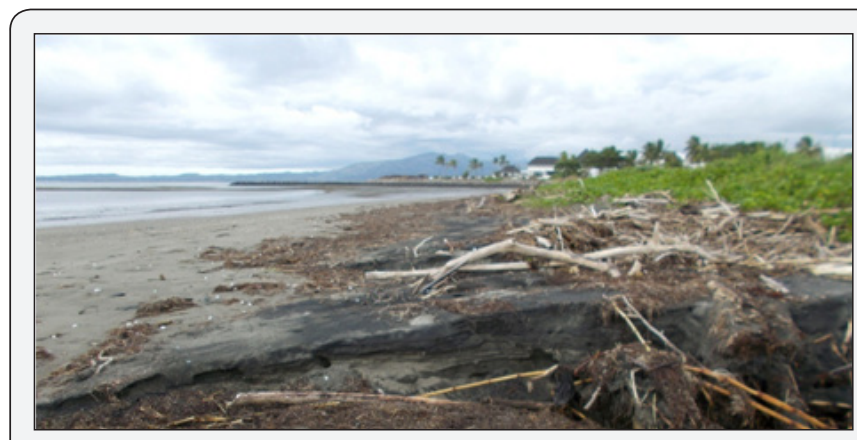

Figure 8: The shore morphology at Denarau indicates coastal stability, lacking any sign of inland migration, rather there is a vegetation zone advancing seawards.

\section{The Denerau Site}

Our first contact with the shores of the Fiji Islands occurred at Denarau. The first observation was that there are absolutely no indications of the shore advancing inland due to sea level rise, on the contrary sea level seems to remain quite stable (Figure 8).

A second observation was that there was an upper limit of dead Patella shells, and a lower limit of living Patella shells (Figure 9). The difference in elevation is $10-20 \mathrm{~cm}$, and may suggest that there has been a lowering of sea level in sub-recent time.

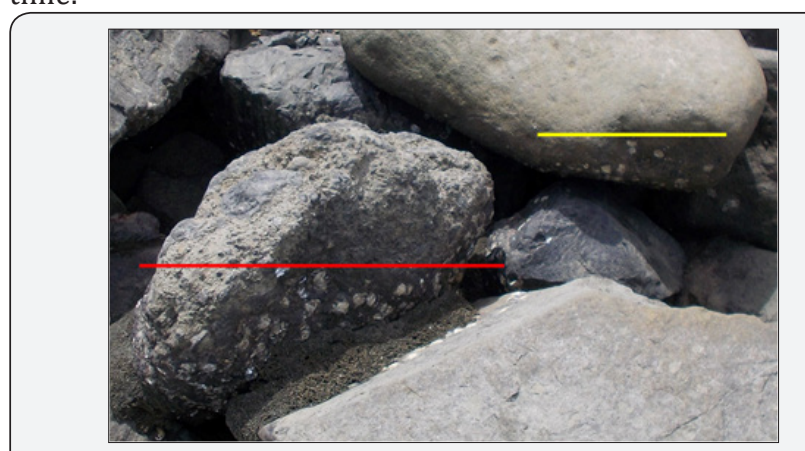

Figure 9 : The blocks are full of Patella shells with an upper limit of dead shells (yellow line), and a lower limit of living shells (red line). This may record a $10-20 \mathrm{~cm}$ lowering of sea level in sub-recent time. 


\section{The Maui Bay site}

At Maui Bay Public Park, on the south coast some $21 \mathrm{~km}$ east of Sigatoka, the accidental find of an interesting site of past sea level changes led to some important discoveries. There is a thick beachrock deposit outcropping in the intertidal zone of the present beach. Also, there is clear evidence of a somewhat higher sea level. In an erosional depression of a small brook, we found a stratigraphic section, documented in Figure 10. Three generations of shore deposits can be distinguished.

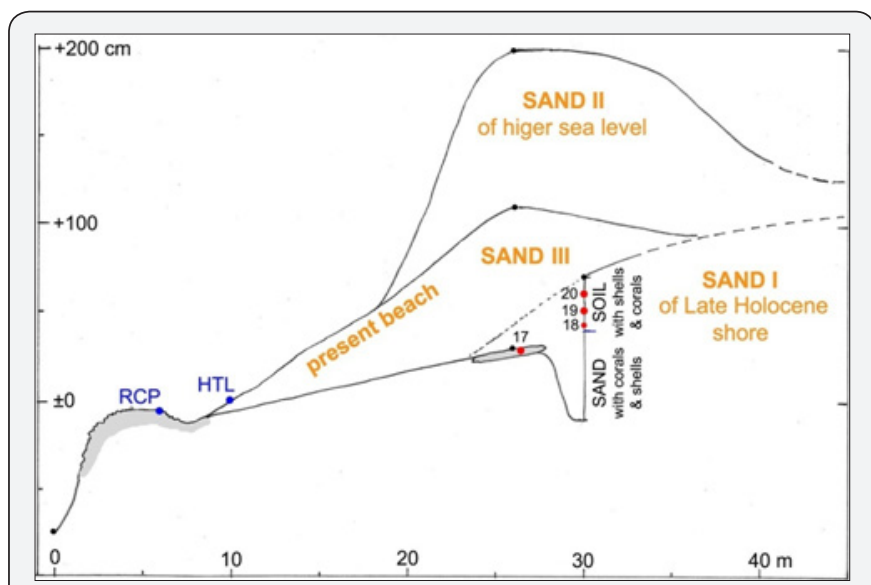

Figure 8 : The section at Maui Bay recording 3 generations of beaches (Sand I-III). HTL=high tide level (the zero level of the section), RCP=rock-cut platform, 17-20=samples.

An extensive beachrock deposit has its surface planed into a rock-cut platform (RCP). The high water level was found in direct association only $5 \mathrm{~cm}$ higher (HTL). The present beach sand deposition, unit III, goes up $110 \mathrm{~cm}$ above HTL (zero in Figure 10). An older over-grown sand unit (II) goes up $90 \mathrm{~cm}$ above the top of unit I, indicating that sea level at one time must have been higher than today by about $90 \mathrm{~cm}$ or a bit less.

Underneath these sand units, there is a third unit (I). It has a $30 \mathrm{~cm}$-deep soil at its top, indicating considerable age. A piece of pottery was found at a depth of $10 \mathrm{~cm}$ (sample 20 in Figure 10), indicating that the soil and sand unit has to be of Late Holocene age. Shells and corals at a depth of $20 \mathrm{~cm}$ (sample 19) were C14dated at $4244 \pm 26 \mathrm{BP}$, or $4345 \pm 100$ cal.yrs. BP. A $10 \mathrm{~cm}$ thick bed of flint-hard beachrock occurs close by. Corals from this bed (sample 17) were C14 dated at $4005 \pm 26$ BP, or $4019 \pm 103$ cal.yrs. BP. This means that shore unit I has an age of about $4182 \mathrm{cal}$. yrs BP (the mean of the two samples). Obviously, sea level had reached the present level, but hardly above this level (at least not more than $0.5 \mathrm{~m}$ ).

A sea level at about $\pm 0.0 \mathrm{~m}$ at about $4200 \mathrm{BP}$ is in minor contrast to the results of [5], who has a Holocene sea level maximum at $+0.45 \mathrm{~m}$ at 5300cal.yrs BP. Ash and Ash [39] demonstrated that a proposed $+1.6 \mathrm{~m}$ Holocene maximum [40], in fact, was only at a $+0.48 \mathrm{~m}$ level (MTL). A sea level at about $+0.4-0.5 \mathrm{~m}$ would agree with all three records, however, but strongly contradict a $+2 \mathrm{~m}$ level as suggested by [16].

The piece of pottery found in the soil (sample 20) with a date of $4019 \pm 105$ cal.yrs. BP implies that Lapita people are likely to have already arrived on Fiji by $4000 \mathrm{BP}$. As this is earlier than considered before (e.g. $[10,33,35]$, it seems necessary to show the piece of pottery (Figure 11).

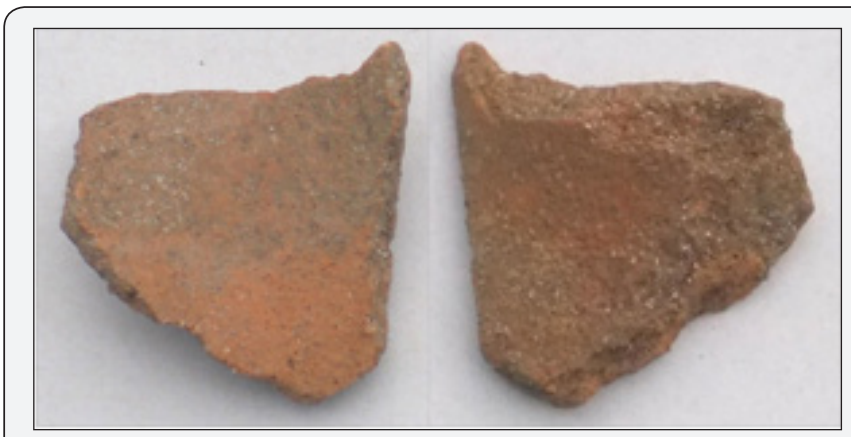

Figure 11 : A piece of pottery found in a soil developed in shore unit I dated at about $4000 \mathrm{BP}$ (sample 19), suggesting that the Lapita people had already arrived at Fiji by 4000 BP.

\section{Results from the Yasawa Islands}

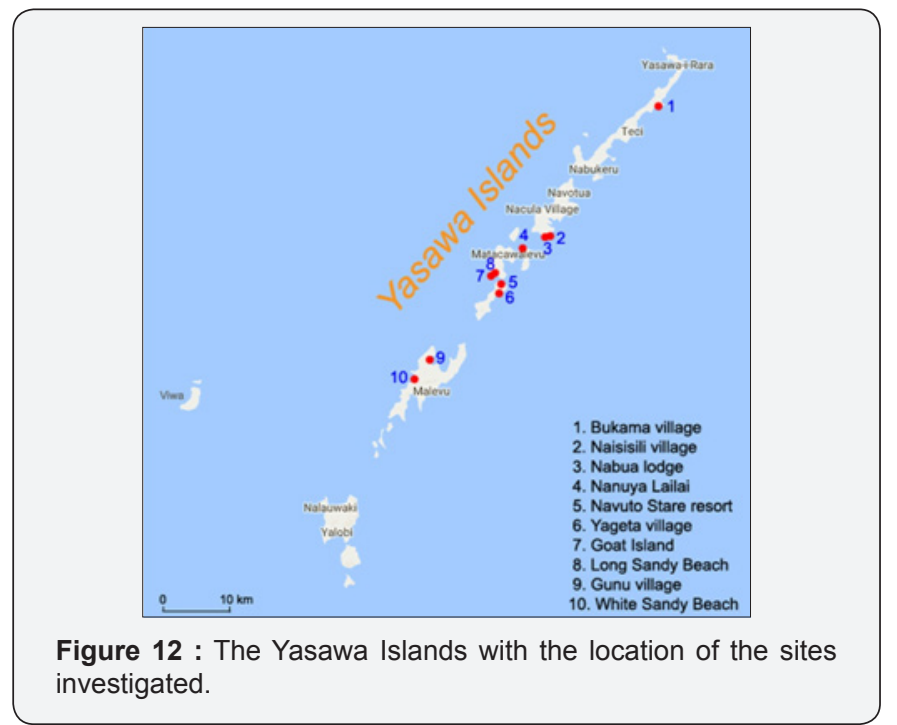

The Yasawa Islands is a chain of six main islands and numerous smaller islets spanning $80 \mathrm{~km}$ in a SW-NE direction (Figure 12). The islands were not charted until 1840. All islands consist of volcanic bedrock (Figure 13). Erosional products generate coastal sand beaches. We undertook detailed sea level studies in 10 separate places. In addition, we made important observations of the coast from the ferryboat as well as the small boats we used for local transportation. As part of our planning for this investigation, we studied all of the islands on Google Earth images.

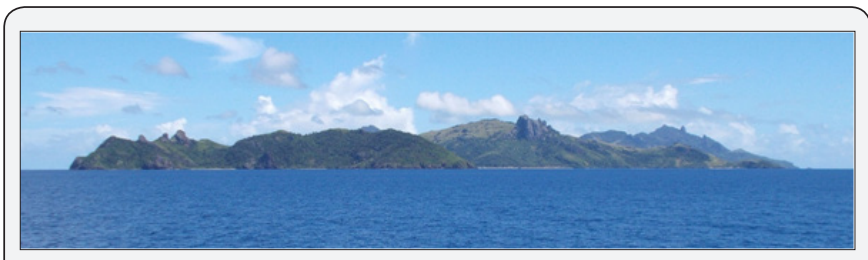

Figure 13 : The Yasawa Islands consists of volcanic rocks. The topography is rough. Today, the islands seem to be dominated by a regional crustal stability. 
At Viwa Island $25 \mathrm{~km}$ to the west of the main Yasawa Islands, three coral samples have been $\mathrm{Th} / \mathrm{U}$-dated at the Last Interglacial [8], viz. $126 \pm 7 \mathrm{ka}$ BP from $+2.1 \mathrm{~m}, 128.7 \pm 1.6 \mathrm{ka}$ BP from $2.85 \mathrm{~m}$, and $136 \pm 12 \mathrm{ka}$ BP from $+3.1 \mathrm{~m}$. According to [14] "no relatively emerged features of certain Holocene age are known from the Yasawa and Mamanuca Islands". This statement seems valid even today (except for the $+70 \mathrm{~cm}$ level described below).

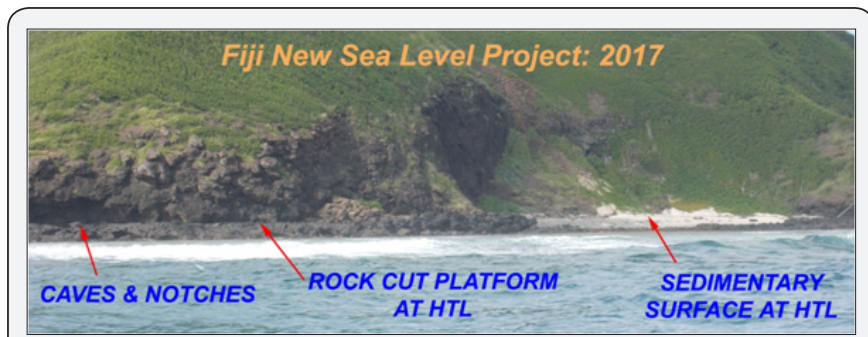

Figure 14 : The distinct shore features marking the HTL, used as our datum for leveling $[11,25]$.

The present shore forms a distinct line all around the islands of rock-notches, sea-caves and rock-cut platforms, as well as sandy beaches (Figure 14). These morphological elements are closely tied to mean HTL, and therefore constitute an ideal datum for our investigations. Levelling was undertaken with a high-precision Kern instrument with rod-readings of up to 0.5 $1.0 \mathrm{~cm}$ accuracy.

\section{General coastal observations}

All the way from Kuata Island in the south to Bukama Village in the north, we observed very distinct shore morphological elements indicating the HTL; i.e., bedrock notches, under-cut notches, rock-cut platforms, and sandy shore HTL marks.

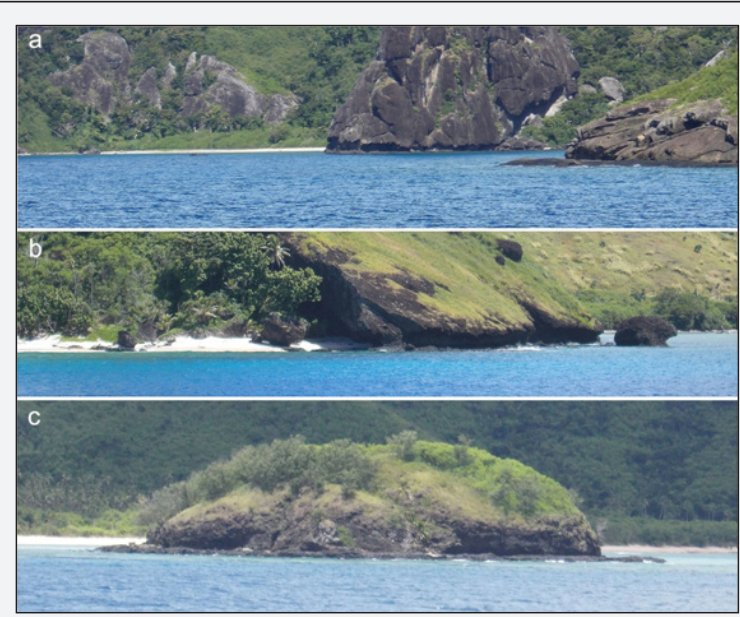

Figure 15 : (a) top: sandy shore, under-cut notch and rock-cut platform at Kuata Island, referring to HTL, (b) middle: under-cut notches of HTL at Waya Lailai Island, (c) bottom: bedrock island surrounded by notches and rock-cut platforms cut at HTL.

A few examples of the distinct high-tide shore markers are given in Figure 15a-c. At some coastal segments it seems evident that the coastal sand is also graded to a somewhat higher level $(+1 \mathrm{~m}$ or less), now overgrown and not reached by the waves at the present sea level. This seems to indicate that there was, in sub-recent time, a higher sea level on the order of +0.5 to $+1.0 \mathrm{~m}$ (Figure 16a-b).

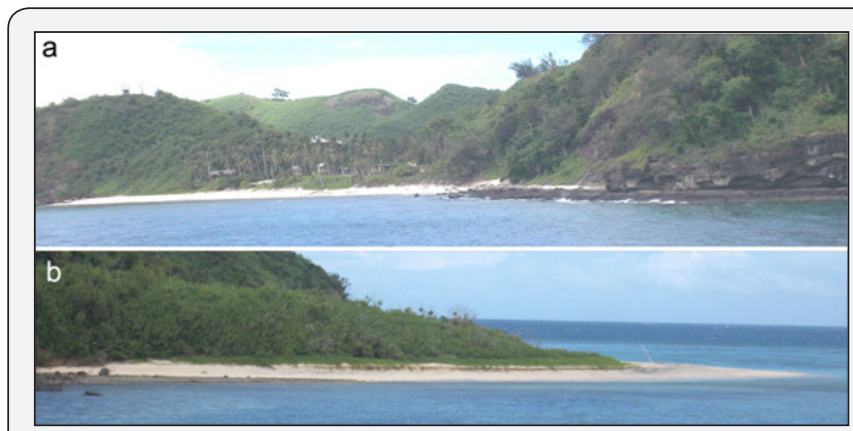

Figure 16 : (a) top: the present sandy beach, the bedrock with distinct notch and rock-cut platform, and a higher sandy shore, now overgrown and inhabited, and (b) bottom: a present HTL with distinct notch of the corresponding washing limit. The overgrown surface above represents a former shore at a somewhat higher sea level.

There seems to be a general lack of higher shore marks, either from a Late Holocene sea level maximum (as proposed by [16]) or from a Last Interglacial level (as found on Viwa Island to the west).

\section{Bukama Village}

We spotted the coast at Bukama Village on the Google Earth images and were attracted by sandy beaches disappearing against rock cliffs and a tombolo spit (Figure 17), both structures of which had a potential for recording changes in present sea level. We accessed the site via a $25 \mathrm{~km}$ long boat ride from Nabua lodge. This ride provided excellent coastal views of distinct shore morphological features indicating the HTL (under-cut notches and sea caves) and sand beaches with the present HTL clearly visible and an older, overgrown, higher surface from a somewhat higher sea level at about $+0.5-1.0 \mathrm{~m}$.

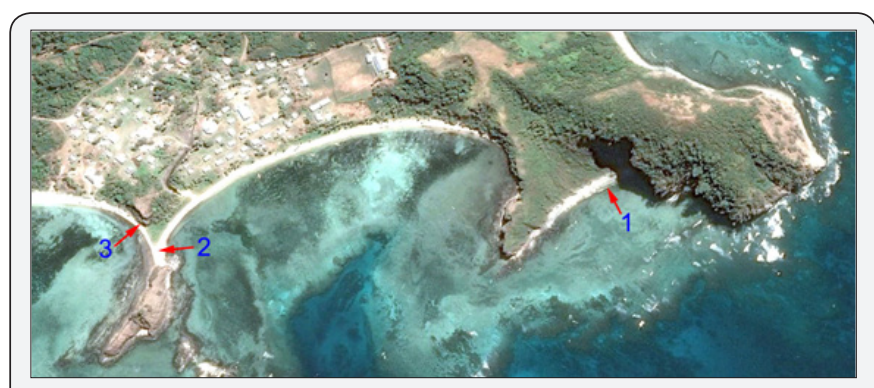

Figure 17 :The Bukama site from Google Earth. (1) shore with beachrock, (2) tombolo subjected to precise leveling, and (3) notches in the bedrock side.

An extensive beachrock at point 1 (Figure 18) was C14-dated at $\mathrm{AD} 611 \pm 82$ cal.yrs. This implies that sea level at that time was at about the same level as today. Judging from the Qaranilaca Cave section on Vanuabalavu Island (section 1.4.2, above), this 


\section{Oceanography \& Fisheries Open access Journal}

level was followed by a lower level lasting from about AD 660 to 1160 [35].

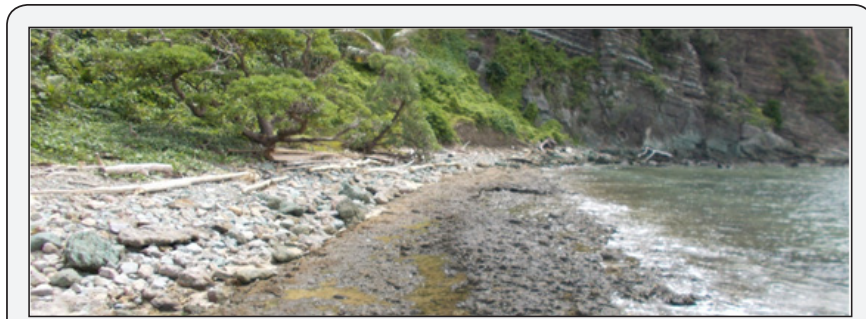

Figure 18 :The shore to the east of Bukama Village, point 1. An extensive beachrock occurs in the intertidal zone just below HTL. It is cut into a rock-cut platform. Shells from the beachrock were $\mathrm{C} 14$ dated at $1339 \pm 82 \mathrm{cal}$. yrs. BP or AD $611 \pm 82 \mathrm{cal}$. yrs.

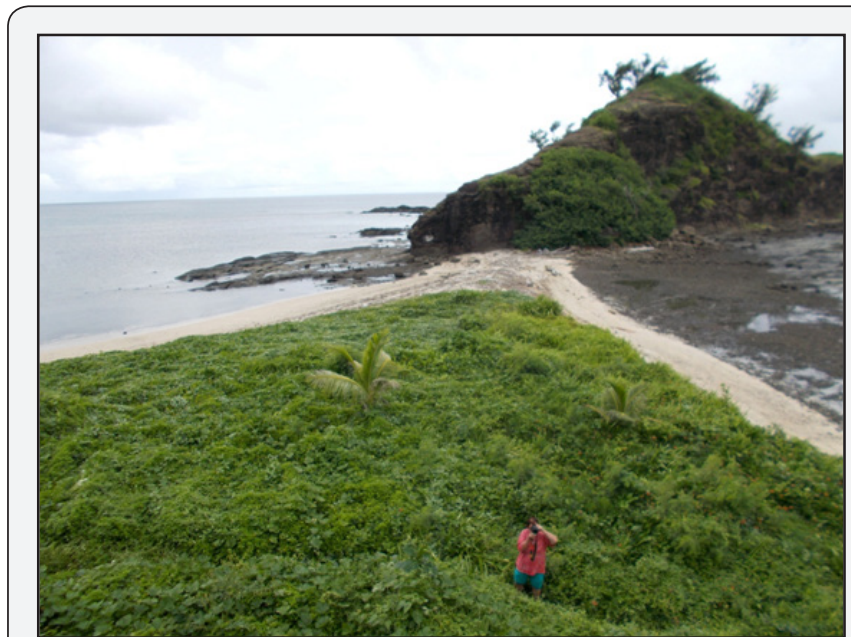

Figure 19 :The Bukama tombolo consisting of an older and higher part, now overgrown, and a still active sandy spur where the crest height corresponds to the washing limit (Figure 20).

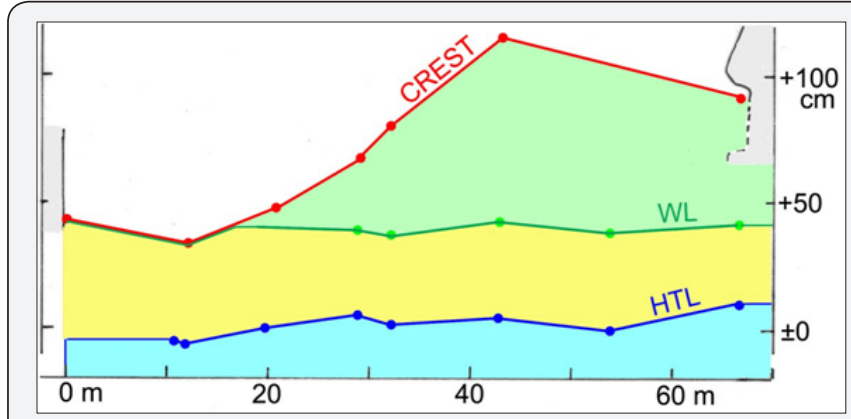

Figure 20 : Leveled section of the tombolo; its crest falling-off to the south and the washing limit (WL) and high-tide level (HTL) on both sides of the tombolo. Green = vegetated surface and grey $=$ bedrock (with a fossil under-cut notch to the right).

The tombolo spit is built out between the mainland and a small island (Figure 17). Figure 19 gives a view from the bedrock hill seawards. The tombolo is built out from the north to the south by converging long-shore drift. The crest, the washing (swash) limit (WL), and the HTL on both sides were leveled with our high-precision instrument (Figure $19 \& 20$ ). The vegetated part is no longer reached by normal waves, and was partly formed at a somewhat higher sea level. The crest is successively falling off to the south and there is a total lack of any signs of present rise in sea level, on the contrary stability is evident. At the foot of the rock hill, there is an old, inactive under-cut notch, now filled by sand (Figure 21a). It must have been cut at a former sea level somewhat higher than today. The leveling indicates that the former sea level must have been about $70 \mathrm{~cm}$ higher than today (Figure 20). Besides the $+70 \mathrm{~cm}$ notch, there are erosional marks in the bedrock at $+2.4-2.6 \mathrm{~m}$ and at $+5.5 \mathrm{~m}$ (Figure $21 \mathrm{~b}$ ). Those marks perhaps represent former sea level notches. We are not sure how to classify them, and leave the question open by assigning them "possible higher sea level notches". No other site with higher notches was observed between Naisisili and Bukama (Figure 22). At Naisisili, there might be one (Figure 31).

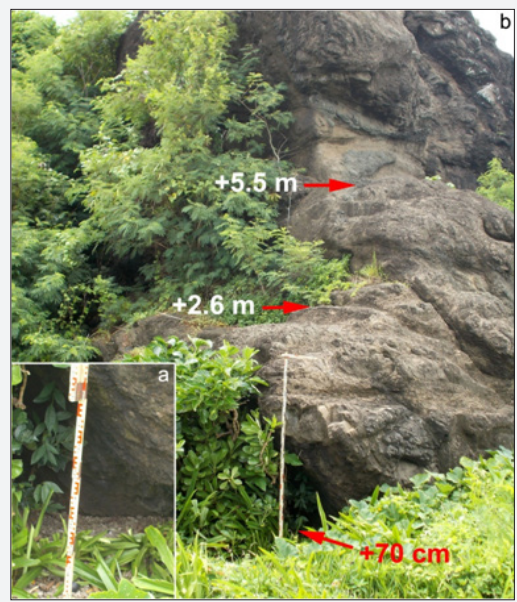

Figure 21 :(a) Inserted: The sand-filled and overgrown $+70 \mathrm{~cm}$ under-cut notch. (b) the same notch with two "possible higher sea level notches" at +2.6 and $+5.5 \mathrm{~m}$.

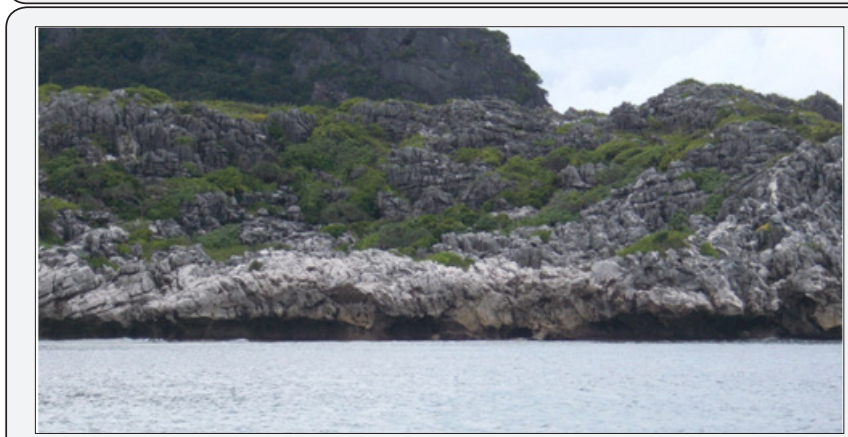

Figure 22 :A typical shore between Naisisili and Bukama; a distinct under-cut notch and no traces of higher notches.

\section{Nabua Lodge and Naisisili Village}

This site was selected because the Google Earth image showed a long coastalspur (Figure 23), which by precise leveling might provide insight into the present trend of sea level; whether rising, stable or falling. Naisisili Village lies on a sandy flat between the sea and a small brook running parallel to the shore for about $600 \mathrm{~m}$. Today, the area of the village is not reached by the normal waves. The sandy ground of the village represents littoral swash deposits at a former sea level in the order of 0.5 $1.0 \mathrm{~m}$ higher than today's sea level. The shore spur to the south is graded to a lower level. The situation is illustrated in Figure 24. 


\section{Oceanography \& Fisheries Open access Journal}

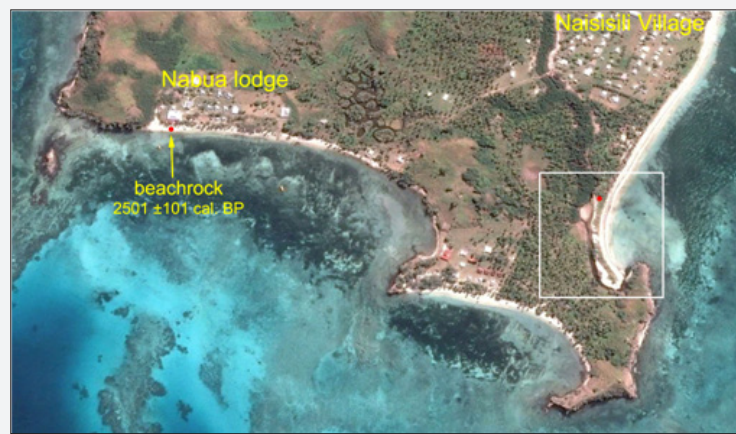

Figure 23: The Nabua-Naisisili sites. The shore spur south of Naisisili Village was our main target for precise leveling (rectangle marking Fig. 24). The bedrock peninsula to the SW has excellent notches, sea caves and rock-cut platforms at the present sea level. The shore at Nabua lodge has extensive beachrock deposits, C14-dated at $2501 \pm 101$ cal.yrs. BP.

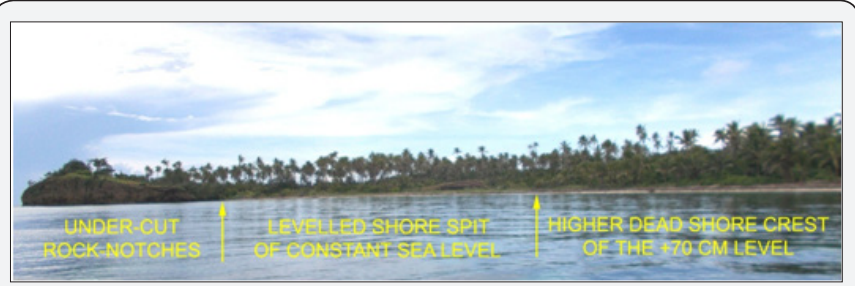

Figure 24: The coastal segment south of Naisisili Village and its morphological subdivision into three zones.

The shore spur (spit) was subjected to precise levelling with 7 sections crossing the spit, identifying the present HTL, the sand/vegetation limit, the crest on the seaside, and the lagoonal HTL both the inner side and the foot of the back-side escarpments (Figure 26).

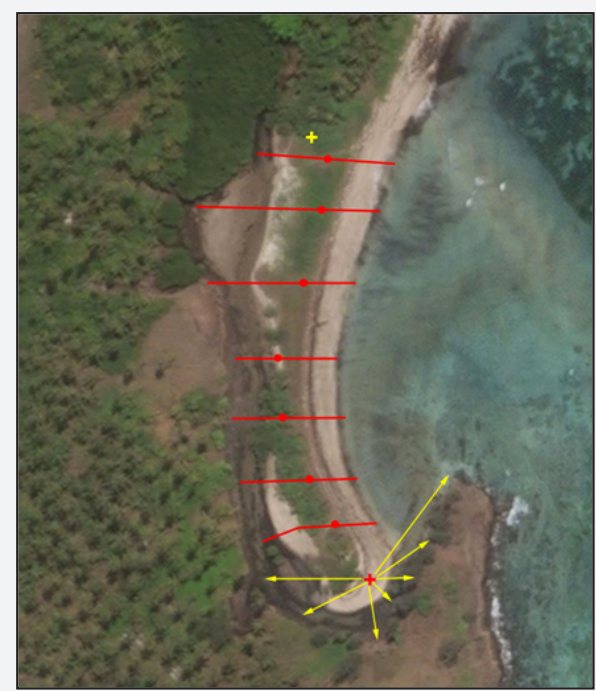

Figure 25: The shore spur south of Naisisili Village, successively being built out between the sea and brook. The spur was traversed by 7 precise leveling sections and an additional point from where related shore marks in the bedrock were leveled (yellow arrows). Yellow cross marks the point of a C14-date of shells at a depth of $30 \mathrm{~cm}$ giving an age of AD $1866 \pm 82 \mathrm{cal}$. yrs, implying that the spur has grown at a speed of about $1.0 \mathrm{~m}$ per year.
Figure 26 gives the main levels identified along and across the shore spur. The crest falls off from around $+2 \mathrm{~m}$ in the north to $+1.5 \mathrm{~m}$ in the south. The shore spur is $155 \mathrm{~m}$ long. A C14-date of shells $30 \mathrm{~cm}$ below surface gave an age of $532 \pm 23 \mathrm{BP}$, which in calendar years is AD cal. $1866 \pm 82$. Assuming an age of about 150 years for the spur to form, it would have been built out to the south at a speed of about $1.0 \mathrm{~m}$ per year, which seems quite reasonable.

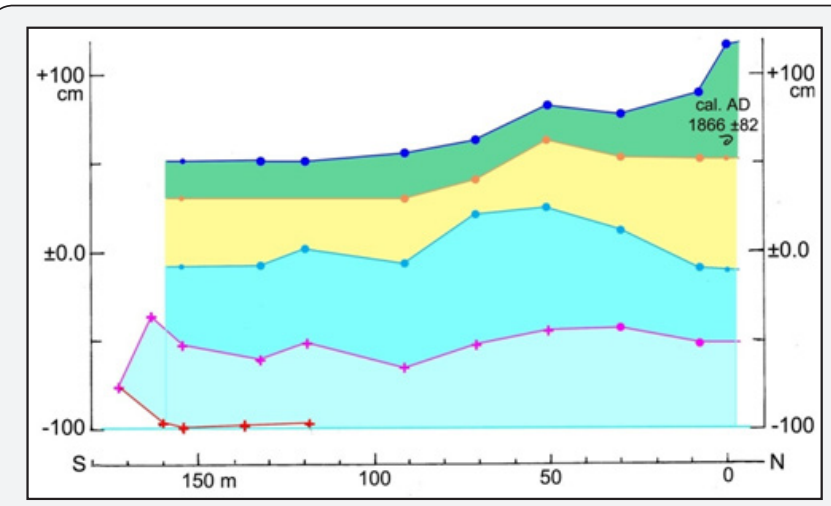

Figure 26: Leveled section of the shore spur (Fig 25). Blue dots and line $=$ crest of the spur. Yellow dots and line $=$ limit between shore sand and vegetation representing present day washing limit. Light blue dots and line = marks of assumed HTL on the shore side. Purple line gives HTL on the lagoonal side with dots referring to sedimentary HTL marks, and crosses referring the foot of erosional scarps. Red line and crosses = under-cut notches in bedrock to the south of the spur, originally used as local benchmark and zero level, now reinterpreted in terms of a former HTL when sea level was about $1.0 \mathrm{~m}$ lower at a period just preceding the building out of the spur; viz. probably from the 18 th century.

It has taken quite some time and checking of photos at both high- and low-tide to decipher the genetic origin of the red, purple and light blue levels in Figure 26. The foot of the undercut notches (red crosses) forming a perfectly straight level (Figure 26) are neither cut at present HTL nor MTL, but at HTL of a former sea level lower that the present one. In the field, we noted that there was a wide rock-cut platform $20-30 \mathrm{~cm}$ above low tide level (LTL). Subsequent observations at White Sandy Beach (below) revealed a similar rock-cut episode at a low-stand prior to the building out of the shore spur here discussed.

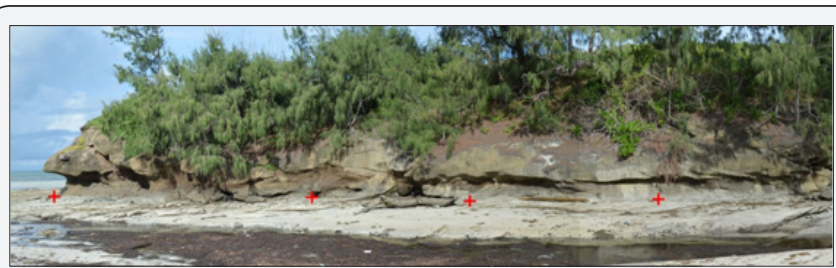

Figure 27 : The sequence of distinct under-cut notches south of the shore spur and the brook outlet. The foot of the notch was leveled at four points (red crosses) with a difference of only $3 \mathrm{~cm}$. Whilst the upper base of the notches corresponds to present HTL (Figure 28), the leveled foot of the notches represents a former HTL, when sea level was about 1.0m lower 


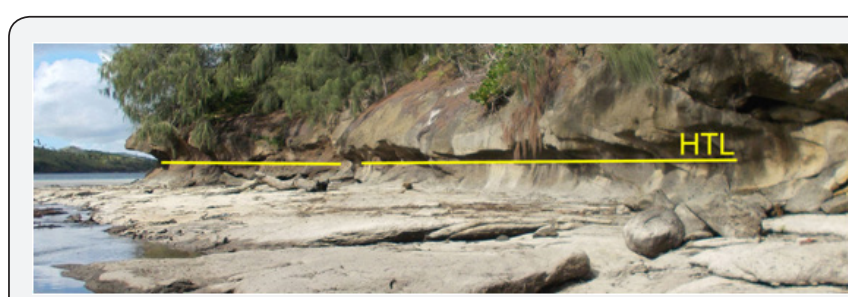

Figure 28 : Present HTL is at the top of the under-cut notch. The foot of the notches and the top of the rock-cut platform lies somewhat below present day MTL, and refer to the HTL at a former and about $1.0 \mathrm{~m}$ lower sea level.

Figures $27 \& 28$ give the sequence of under-cut notches along the bedrock just south of the shore spur and the brook outlet. Present HTL corresponds to the top of the notch, where the flat or concave surface starts to bend out again (yellow line in Figure 28). The leveled base of the notches (red crosses) in Figure 27 corresponds to a former HTL (present MTL lies above).

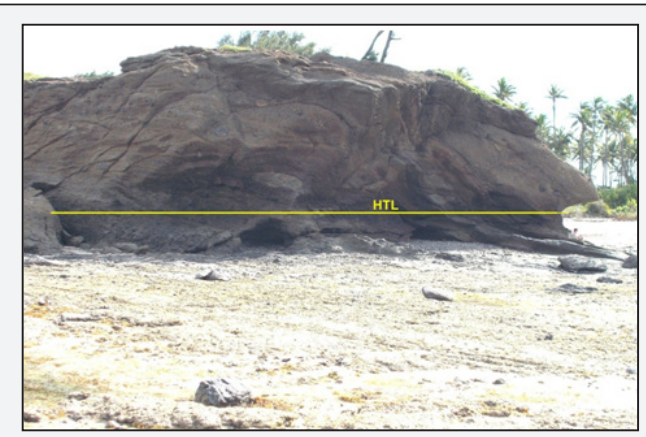

Figure 29: The present HTL is at the innermost point of the under-cut notch. The foot of the cliff with its sea caves refers to the HTL of a former and lower sea level. The same applies to the extensive rock-cut platform, today about $20-30 \mathrm{~cm}$ above present LTL.

In summary, we document a former, lower sea level with its HTL about $100 \mathrm{~cm}$ below the present HTL (Figure 26). The foot of the cliff (Figure 29) and the notches (Figure 27) goes over into an extensive rock-cut platform extending about $20-30 \mathrm{~cm}$ above present LTL. This former, lower sea level must have preceded the formation of the shore spur. The shore spur, on the other hand, seems to have been built out during a more or less constant sea level during the last 150, maybe 200, years. Therefore, it seems likely that the low sea level stage belongs to the 18th century. This story is built on the observational facts observed at Naisisili, but the full interpretation is admittedly influenced by observations and C14-dates to be discussed later in this paper (especially sections Goat Island, and White Sandy Beach).

Comparing pictures taken at low-tide and high-tide respectively, clearly indicate that present day HTL lies well above the major sea level marks in the form of the foot of cliffs, the base of notches, the floor of sea caves and the top of rock-cut platforms (Figure 30). At Bukama Village, we had some bedrock structures that might represent sea notches at $+2.6 \mathrm{~m}$ and $+5.5 \mathrm{~m}$ (Figure 21). For the rest of the $25 \mathrm{~km}$ between Bukama and Naisisili no such levels were recorded, however (Figure 22). At the southeastern tip of the peninsula south of Naisisili Village (Figure 31 ), there is a very clear bedrock bench that might represent a former sea level at about $+2-3 m$ (Figure 31). At Wiva Island, [8] reviewed three coral samples collected at elevations ranging from +2.1 to $+3.1 \mathrm{~m}$ and dated at the Last Interglacial. Our Figure 23 notch may therefore represent a Last Interglacial sea level position at about $+2-3 \mathrm{~m}$; i.e. the same level as recorded on Wiva Island and Kadawa Island (Figure 6), but about $2 \mathrm{~m}$ lower than recorded on the Vanuabalavu Islands (Figure 5) Figure 31.

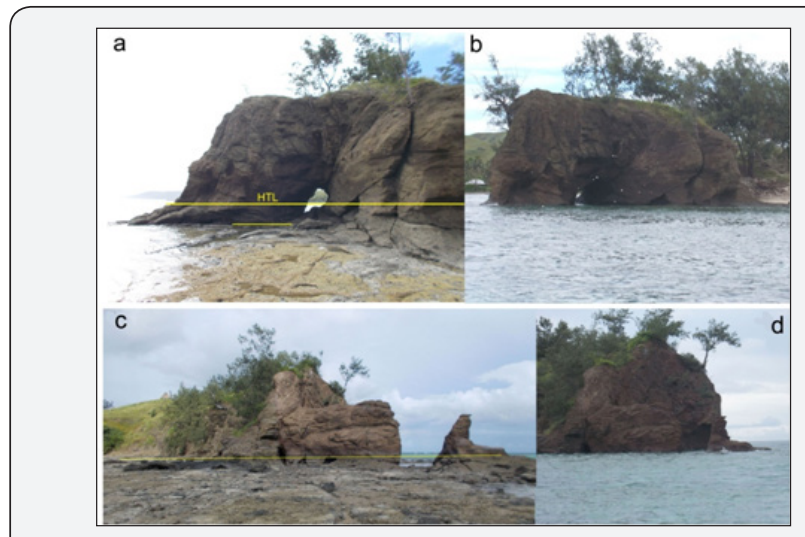

Figure 30: Double pictures taken at low tide (a and $c$ ) and at high tide ( $b$ and $d$ ) indicating the HTL is about $1 \mathrm{~m}$ above the foot of the cliffs and the base of the sea caves.

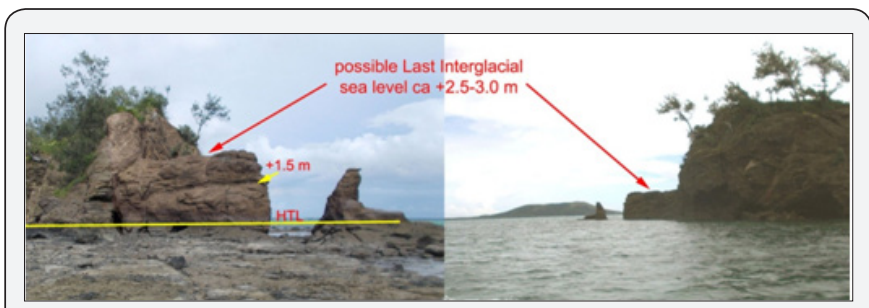

Figure 31 : It seems there may be a fossil shore level at about $+2.5-3.0 \mathrm{~m}$. If so, it might correlate to the sea level at about +2$3 \mathrm{~m}$ on Wiva Island dated to the Last Interglacial.

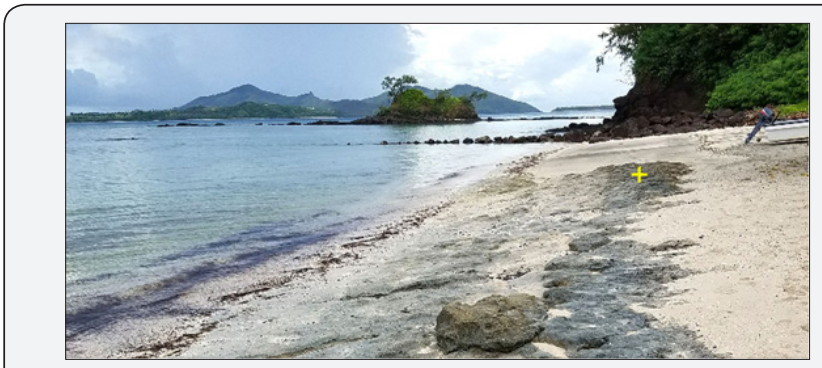

Figure 32 : Beachrock on the shore of Nabua lodge, outcropping in the intertidal zone between MTL and HTL. It includes some corals and numerous shells. Shells from this bed were collected (yellow cross) and dated.

At Nabua lodge, an extensive layer of beachrock occurs all along the shore between MTL and HTL. Shells from the beachrock just outside Nabua lodge (Figure 32; with + marking sample) were sampled and C14-dated at $2799 \pm 25 \mathrm{BP}$ or $2501 \pm 101 \mathrm{cal}$. yrs BP. Beachrock is usually formed just above MTL (but may occasionally even form below mean sea level). Therefore, the age obtained indicates that sea level at about 2500 cal.yrs BP was at about the same position as today. 


\section{Nanuya Lailai Lodge}

A coral reef just off the coast was investigated. A coral colony measured as $130 \times 140 \mathrm{~cm}$ consists of four minor units. All of those have reached a level so close to LTL that they are now growing laterally instead of upwards; i.e. they are "microatolls", with dead centres. The central part of one of the miniatolls $(20 \times 35 \mathrm{~cm}$ wide) was sampled and C14-dated as "younger than 1955" (i.e., after the bomb effect, and hence not dateable).

Close by, there were two corals grown into columnar "chimneys"; one had a flat surface and was dead, while the other was still alive and growing. The difference in elevation between the top of the dead column and the living column was only 5 $\mathrm{cm}$, indicating the very high sensitivity to depth below LTL. The occurrence of microatolls indicates present sea level stability.

\section{Navutu Stars Resort}

At this site, the under-cut notches and rock-cut platforms are closely tied to HTL, as evidenced by Figures $33 \& 34$.

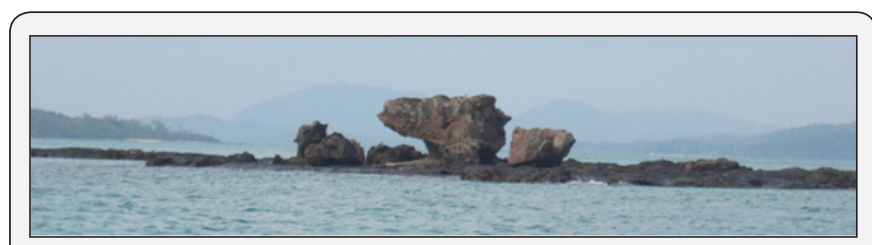

Figure 33 : The island is eroded into a rock-cut platform and the big block has a distinct under-cut notch in direct agreement with the mean $\mathrm{HTL}$.

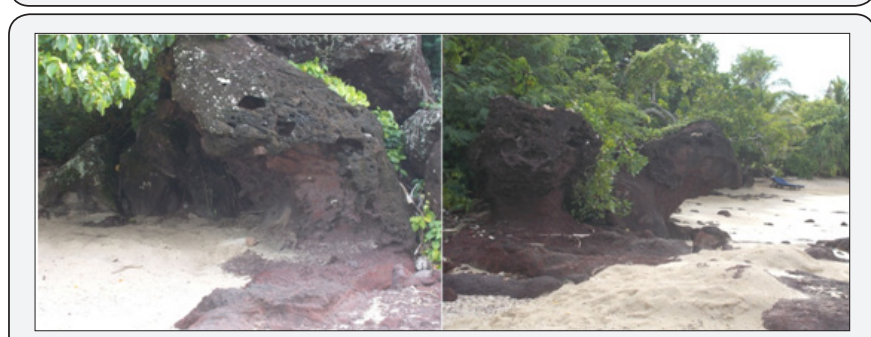

Figure 34 : The under-cut notches at the beach of Navutu Stars correspond to the mean HTL, which is the norm in the Yasawa Islands (cf. Figure 13).

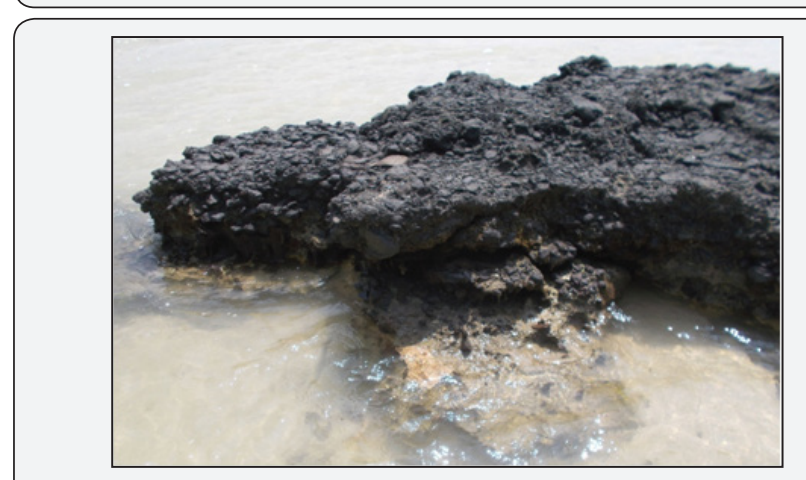

Figure 35 : The beachrock on the shore at Navutu Stars consists of a normal sandy unit with shells (light tan) and an overlying conglomeratic unit (dark) lacking shells, which might represent a colluvium layer deposited at a subsequent sea level lowering.

Beachrock deposits occur at several places around the islands (viz. at Navutu, Yageta, Goat Island and Long Sandy Beach). The beachrock on the shore of Navutu Stars consist of a lower sandy beachrock with occasional shells covered by a conglomeratic gravel unit (Figure 35). Shells from the lower unit were dated at $4331 \pm 60$ BP or $4479 \pm 180$ cal.yrs BP $(2529 \pm 180$ cal.yrs BC).

\section{Yageta Village}

The shore of Yageta Village has been heavily eroded over the past ten years. This has nothing to do with sea level changes, but is the effect of the removal of thousands of sea cucumbers as further discussed in [41].

The village is located on a flat sand plane, which seems to represent littoral deposits from a time when sea level was about $0.5-1.0 \mathrm{~m}$ higher than today. A sandy beachrock with shells occurs on the present shore (between MTL and HTL). A sample of shells was collected but not dated.

\section{Goat Island}

This site was chosen because of its easy access to the strait between Goat Island and Long Sandy Beach. Here Google Earth images showed strong currents and re-deposition of sand, which might record the trend in present sea level; whether rising, falling or remaining virtually stable (Figure 36).

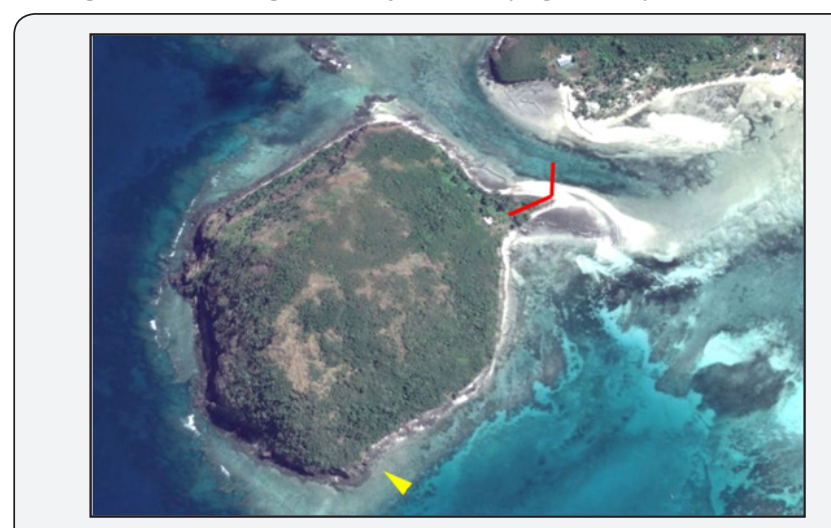

Figure 36 : Goat Island with location of leveled section with microatolls (red line), and views of shore segment and big sea cave, including a higher notch (yellow wedge).

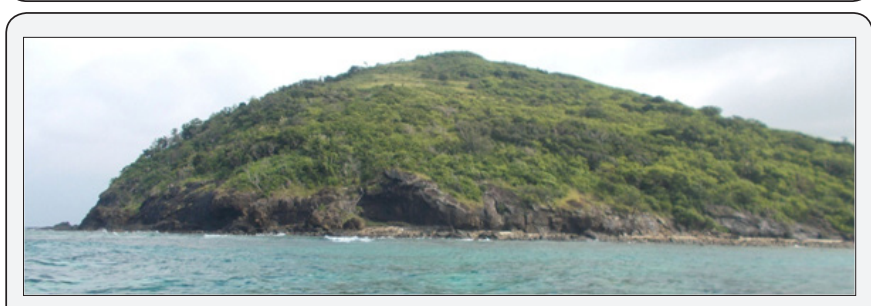

Figure 37 : The southeast shore of Goat Island showing the base of large sea caves, the foot of cliff scarps, under-cut notches, surfaces of rock-cut platforms, and sedimentary hightide notches on a perfectly straight line marking the mean HTL.

Most of the coast consists of bedrock with a distinct HTL marked by notches and sea caves, which, on a straight line, grade over into the HTL along the sandy shores (Figure 37). In the northeast, the shore projects a sand wedge into the sea. Here, the present beach has a clearly identified HTL and washing limit (WL) as illustrated in Figure 38. We rapidly made two important 
discoveries, viz. the presence of a former (fossil) shore $30 \mathrm{~m}$ inland, and the occurrence of a coral microatoll off the shore.

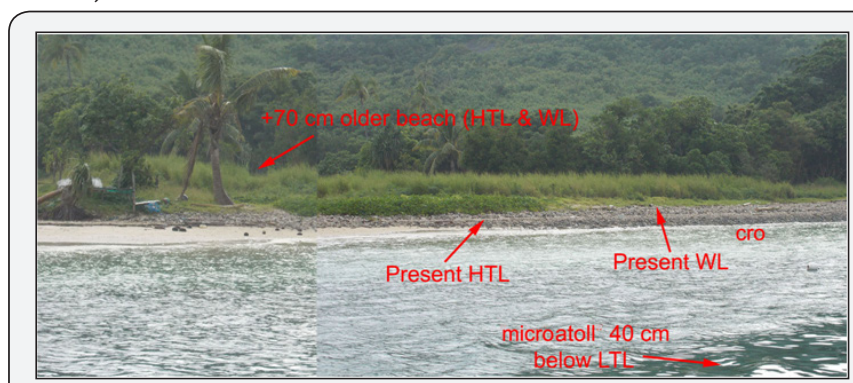

Figure 38 : The shore at Goat Island with clear HTL and WL structures, and the discovery of an older $+70 \mathrm{~cm}$ beach inland and a microatoll offshore underwater.

The old shoreline found inland has morphology almost identical to that of the present shore (Figure 38). There is a difference of $70 \mathrm{~cm}$ between the present and old WL levels $(68 \mathrm{~cm}$ measured), as well as between the present HTL level and the old HTL limit ( $71 \mathrm{~cm}$ measured). Therefore, it was safely assume that $\mathrm{a}+70 \mathrm{~cm}$ former sea level was documented.

Corals from the old $+70 \mathrm{~cm}$ beach were collected and C14dated at $815 \pm 26 \mathrm{BP}$ or cal. AD $1601 \pm 143$. This implies a time within the period of the Little Ice Age climatic conditions. A high level at that time might, therefore, be surprising. It fits very well, however, with the findings in the Indian Ocean with a $+50-60 \mathrm{~cm}$ higher sea level within the period AD 1550-1700 followed by a low level in the $18^{\text {th }}$ century [42].

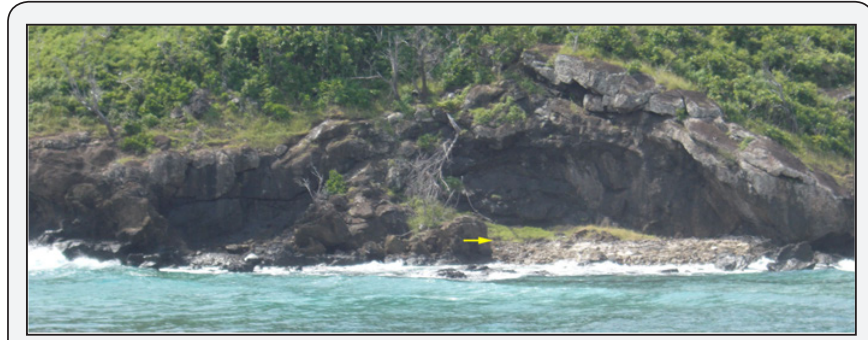

Figure 39 : The big sea cave with its double interior (the boundary marked by a yellow arrow); the present actively eroding level referring to the HTL, and an inner level, now overgrown and inactive. It seems reasonable to correlate it with the $+70 \mathrm{~cm}$ shore recorded $480 \mathrm{~m}$ to the NNE in the leveled profile of Figure 41.

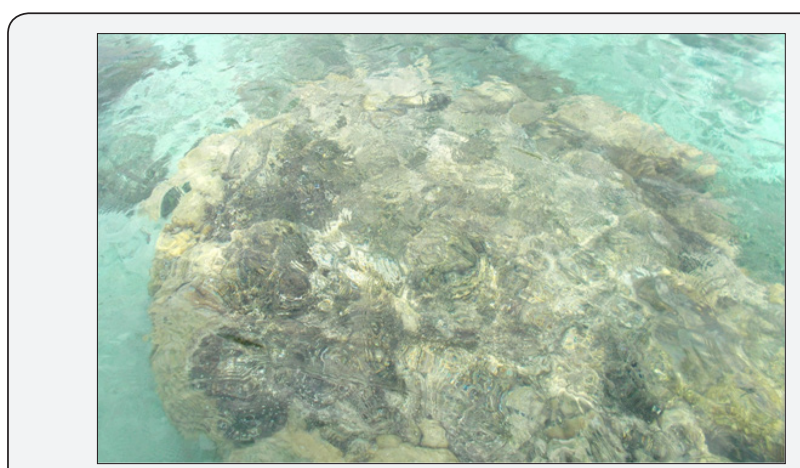

Figure 40 : Coral microatoll as observed when passing over it by boat. Dimension: $110 \times 130 \mathrm{~cm}$.
Within the big sea cave in Figure 37, it seems that there, in fact, are two levels; the present level in full agreement with surrounding shore marks, and an older level at a higher and deeper level in the cave, which is now overgrown and hence inactive and "fossil" (Figure 39).

In the strait adjacent to the leveled section, we observed a large coral microatoll when passing over it by boat (Figure 40). From Navutu Stars lodge, we had the time of the next low-tide the following morning within a 1-minute precision. Despite thunderstorms and heavy rain we were at the site just in time for the LTL. The distance between the top of the microatoll and the sea level at low tide was measured at $40 \mathrm{~cm}$ (Figure 41). This is, of course, a very critical depth, preventing vertical coral growth and forcing it to grow horizontally into a microatoll (Figure 42).

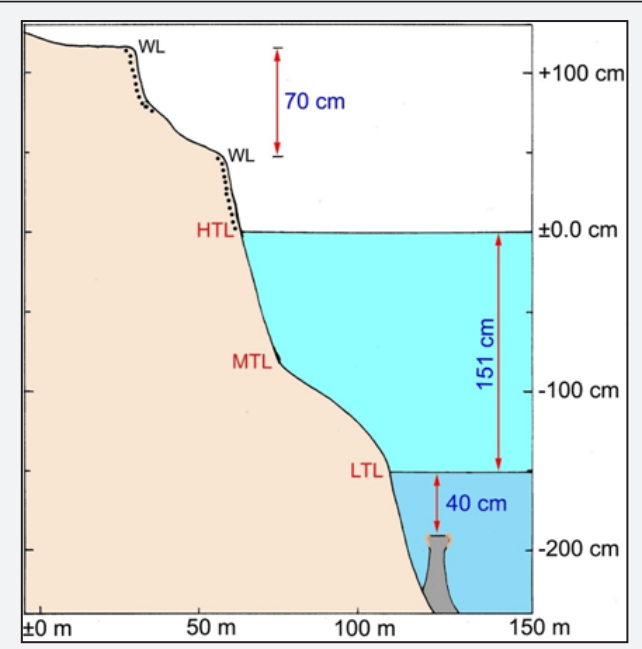

Figure 41 : Leveled section over the present beach with its HTL and WL marks, in over the fossil shoreline with its clearly identified HTL and WL levels, and out into the sea connecting with the top of the microatoll.

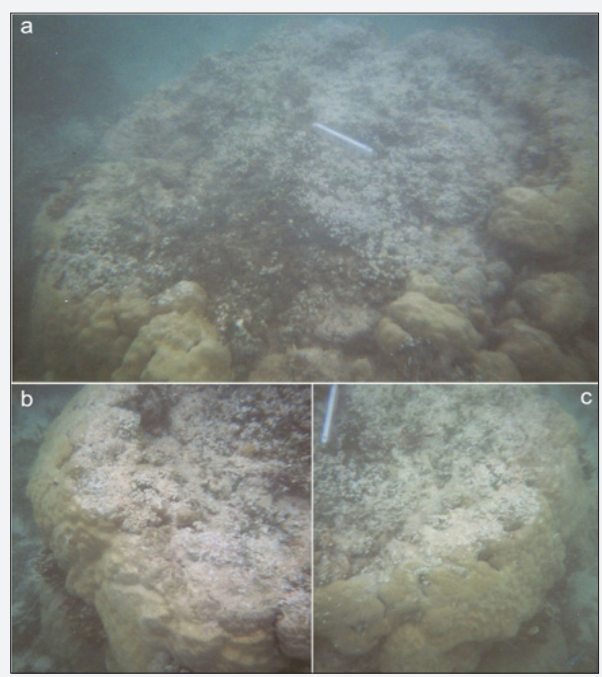

Figure 42 : The microatoll at Goat Island. It rises as a pinnacle from the bottom; $2 \mathrm{~m}$ high and $1.1 \times 1.3 \mathrm{~m}$ wide. The centre is dead and only the edges consist of living corals. The top of the microatoll lies $40 \mathrm{~cm}$ below the LTL. A sample for C14-dating was collected in the centre. Scale: $20 \mathrm{~cm}$ rod. 
We returned the next day, photographed the microatoll under water (Figure 42), measured it, sampled it and tied it into the leveled section (Figure 41). The coral has grown like a pinnacle with a height of about $2 \mathrm{~m}$ and a diameter of $110 \times 130 \mathrm{~cm}$. The surface of the dead coral in the centre of the microatoll was sampled and C14-dated at "106.4 $\pm 0.3 \mathrm{pmC}$ ", implying that it was too young to be dated; i.e. $\mathrm{AD}<1955$.

This seems to imply that the coral had been growing upward in columnar form until, in the mid-to-late $20^{\text {th }}$ century, came so close to the low-tide level that it was forced to change growth habit, growing laterally rather than vertically, thus becoming a "microatoll" with a dead centre. This gives evidence of a stable sea level during the last 50-70 years.

The death of the coral top and centre may be an effect of the 1998 coral bleaching event, or a sub-recent lowering in sea level (cf. Figure 9). At any rate, the occurrence of microatolls at Goat Island provides strong indication of a stable sea level over the last decades to half a century. Microatolls were also observed NW of Goat Island.

\section{Long Sandy Beach Lodge}

A part of the shore at Long Sandy Beach is subjected to coastal erosion. The erosion has nothing to do with changes in sea level, but is an effect of misplaced seawall and jetties, as further discussed in [43].

\section{Gunu Village}

The Google Earth image of the coast at Gunu Village documents a sea level history of 3-4 steps, and a present shore with the building out of double shore spurs (Figure 43). The spurs were subjected to precise leveling in order to see if there were any changes in sea level to be documented (Figure 44).

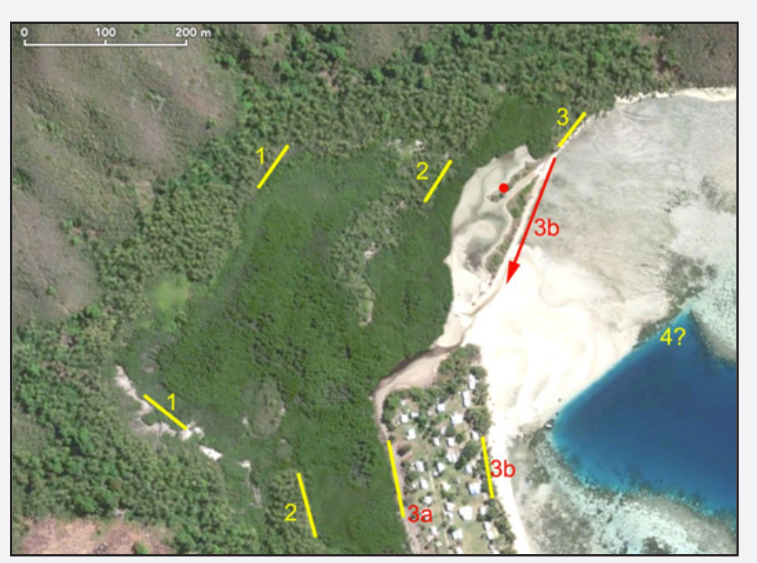

Figure 43 : Gunu Village with morphological remains of 3 or 4 sea level positions; 1 and 2 marks former, now over-grown sea levels, 3 refers to the present shore where $3 a$ refers to the $+70 \mathrm{~cm}$ position in the $16^{\text {th }}$ and $17^{\text {th }}$ centuries and $3 a$ to the present shore and its extension over the $19^{\text {th }}$ and 20 th centuries. The low shore level in the 18th century may be represented by the submarine "4?" level. The double spurs (red arrow) were leveled by high-precision instrument. Red dot marks location of sampling for C14-dating.

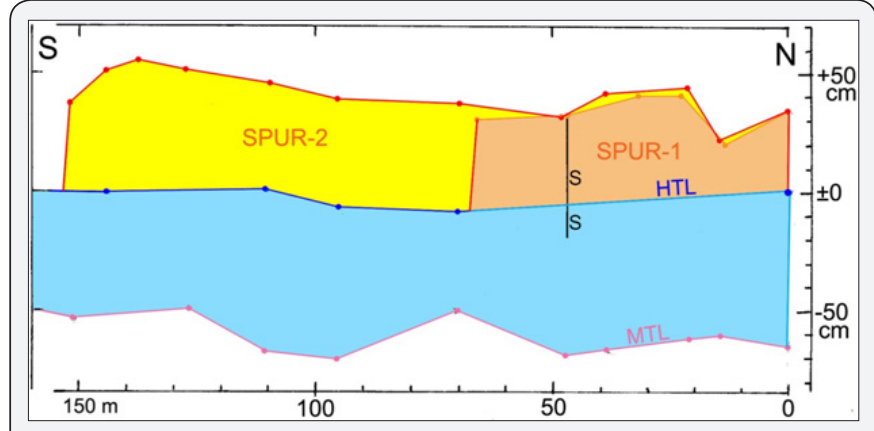

Figure 44 : Leveled section across the two shore spurs at Gunu Village. The MTL, HTL and crest levels of spur 1 and 2 are given. $S$ stands for shells sampled for dating.

Both shore spurs were leveled, in eight crossing sections. Figure 44 shows the HTL, used as local zero level, the MTL and the level of the crest of spur-1 and spur 2. The HTL keeps a constant level across the profile. The MTL level lies about $60 \mathrm{~cm}$ below, which agrees well with the half tidal amplitude at Suva tide-gauge station on Viti Levu. The levels of the crests of spur-1 and spur- 2 are almost identical, showing that the change from one level to the other is related entirely to shore dynamics, and not to any change in sea level. The crest of spur- 2 is slowly rising from $+32 \mathrm{~cm}$ at $47 \mathrm{~m}$ to $+56 \mathrm{~cm}$ at $138 \mathrm{~m}$. This might be interpreted as a slowly rising sea level trend. The last $15 \mathrm{~m}$ are characterized by a distinct lowering in the crest level (the leveling reads $19 \mathrm{~cm}$ ). Under no circumstances, however, is there any indications of a current trend for sea level rise.

Shells were collected in a pit dug at the crest of spur- 1 at a depth of $40-50 \mathrm{~cm}$ below the surface. They were C14-dated at $434 \pm 23 \mathrm{BP}$ or AD cal. $1910 \pm 40$. This seems to suggest that the spur system has built out during the last century, at a mean speed of about 1 to $1.5 \mathrm{~m}$ per year.

Gunu Village itself is located on littoral sand sediments originating from a time when sea level was 0.5-1.0 m higher than today (marked 3a on Figure 43). On Google Earth images there seems to be two additional sea level positions further inland (marked as shores 1 and 2 on Figure 43). They are likely to represent the $+0.3 \mathrm{~m}$ sea level peaks recorded in Viti Levu at about 5300 and 3350cal.yrs BP (Figure 4). The submarine part may perhaps record an additional low sea level (marked 4 ? in Figure 43). It might be the remains of the 18th century low level, recorded in White Sandy Beach (below).

\section{White Sandy Beach Lodge}

White Sandy Beach turned out to become one of our key sites (Figure 45). A short overview report has been presented (Mörner et al., 2017). The various observations will be described below with references to points 1-8 in Figure 45. The present HTL is very well expressed as under-cut bedrock notches and rock-cut platforms at points $1,3,4$ and 8 . The HTL is also well expressed along the sandy shores. The HTL level was used as our zero level. MTL is well expressed in a break in slope of the 
shore profile, and the accumulation of coarser sand grains and fine gravel grains.

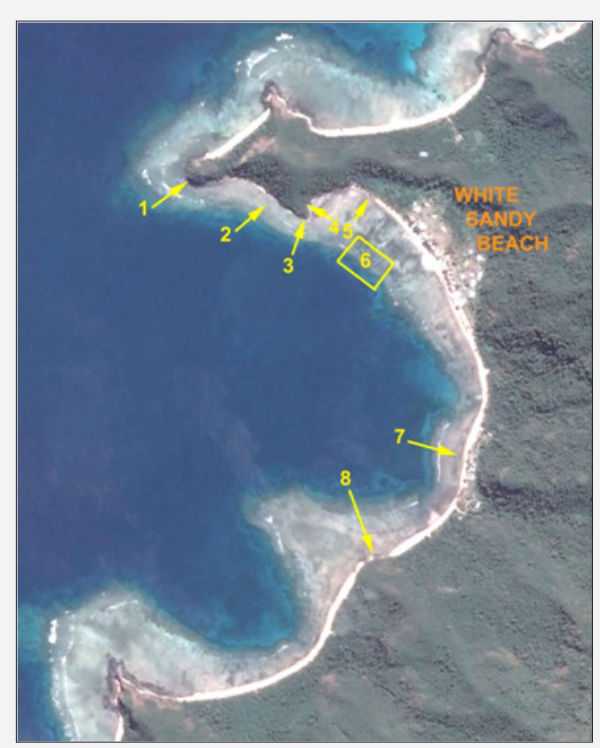

Figure 45 : The embayment at White Sandy Beach. Location points: (1) bedrock shore with present under-cut notches and rock-cut platforms, traces of a higher notch, and the occurrence of a second rock-cut platform with under-cut notches slightly above present LTL (Figure 49), (2) location on beachrock full of corals, which were C14-dated (Figure 55), (3) bedrock with present notches and a wide rock-cut platform, and a clear older and higher bedrock notch leveled at $+70 \mathrm{~cm}$ (Figure 47 ), (4) site of cemented corals beneath down-tumbled blocks (Figure 48), which were $\mathrm{C} 14-$ dated, (5) beachrock along the shore between MTL and HTL, (6) the LTL with $20 \mathrm{~cm}$ emerging dead corals (Figure 50), microatolls with their tops $40 \mathrm{~cm}$ below LTL (Figure 53 ), and coral rubble accumulated outside (Figure 52), (7) an extensive beachrock cut into a rock-cut platform, and (8) an impressive under-cut notch and rock-cut platform closely tied to present HTL (Figure 46).

The LTL is marked by the emergence of an extensive shore flat (tan colour in Figure 45), in its outer zone consisting of dead corals. It represents a former rock/reef-cut platform at about $20 \mathrm{~cm}$ above present LTL. Outside the LTL the depth increases (blue colour in Figure 45) and corals occur, including microatolls with its top $40 \mathrm{~cm}$ below LTL.

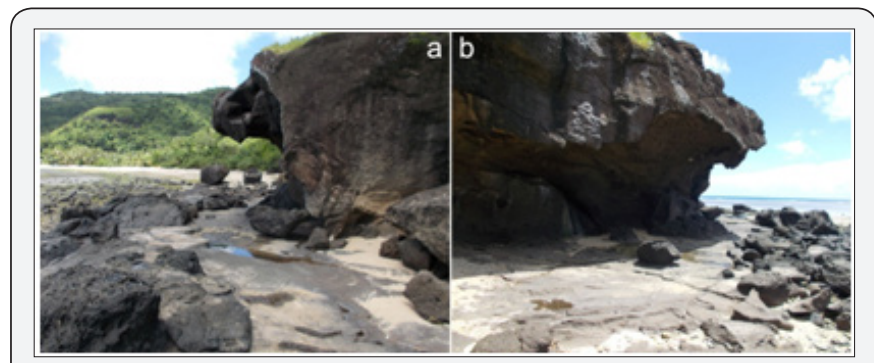

Figure 46 : The deeply under-cut notch and related rock-cut platform at point 8 are closely formed at present HTL, and successively merge over into the HTL of the sandy beach.

At points 1-4 and at point 8 (Figure 44), there are extensive rocks-cut platforms and under-cut notches, which are closely tied to present HTL and merge over into the active HTL of the long sandy beach. At point 8, this is especially clear (Figure 46). Because of the clear relationship between present HTL and the shore morphology (under-cut notches and rock-cut platforms at the rocky coasts, the HTL marks on the sandy beaches, and the observed tidal cycle), we chose the HTL as our zero level.

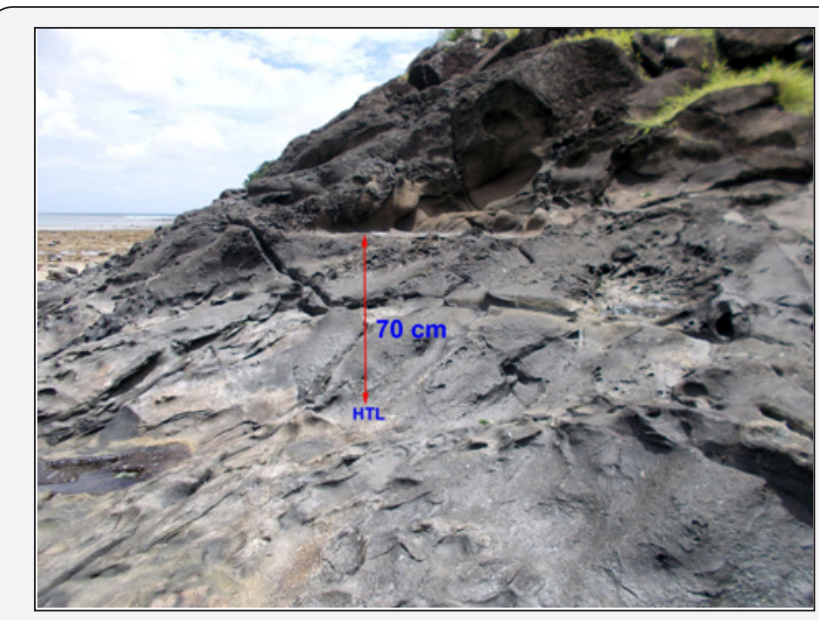

Figure 47 : An old and inactive bedrock notch from a former sea level $70 \mathrm{~cm}$ above the present high-tide marks (point 4 in Figure 45). This is the same height as recorded on Goat Island (Figure 41). Both levels are dated at about AD 1500-1700.

Inside the present-day sandy shore, there is a somewhat higher level of littoral sand, upon which the present houses are constructed. These elevated littoral deposits must represent a former sea level position higher than the present one. At points 1 and 3 , we found bedrock notches above the present HTL. At point 3 , the notch was leveled at $70 \mathrm{~cm}$ above present HTL (Figure 47).

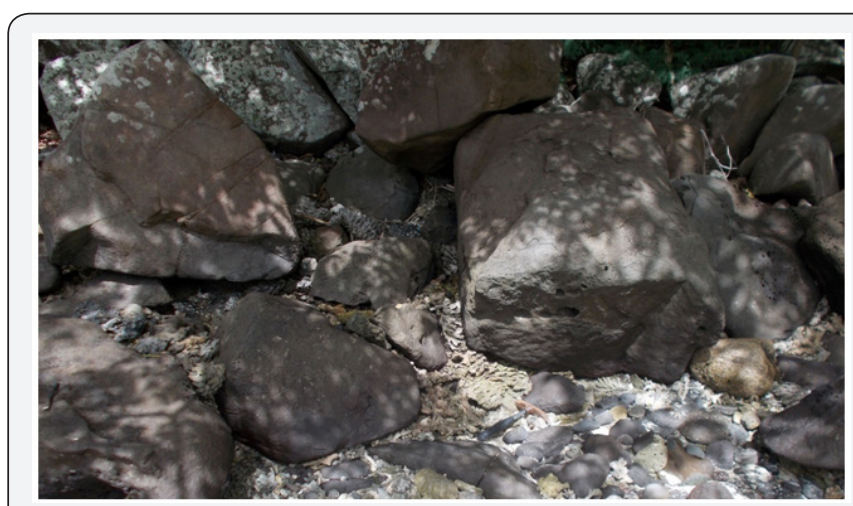

Figure 48: A former and higher accumulation of corals is partly covered by big, downfallen blocks. A coral beneath the block in the middle was dug out and C14-dated.

A former $\mathrm{HTL}$, now $70 \mathrm{~cm}$ above the present $\mathrm{HTL}$, is identical to the records at Goat Island (Figure 41). In association with the $+70 \mathrm{~cm}$ notch, there is an accumulation of corals, now partly covered by downfallen blocks (Figure 48). A C14-date of a coral dug out from a position under a big block gave $847 \pm 24 \mathrm{BP}$ or AD cal. $1576 \pm 71$. This is very close to the age of the $+70 \mathrm{~cm}$ beach on Goat Island dated at AD $1601 \pm 143$. We may therefore, assume that sea level was $70 \mathrm{~cm}$ higher than at present within the period AD 1500-1700, without specifying the beginning and end of 
this period. This fits well with a higher littoral level inside the present sandy beach in sub-recent time (Figure 48).

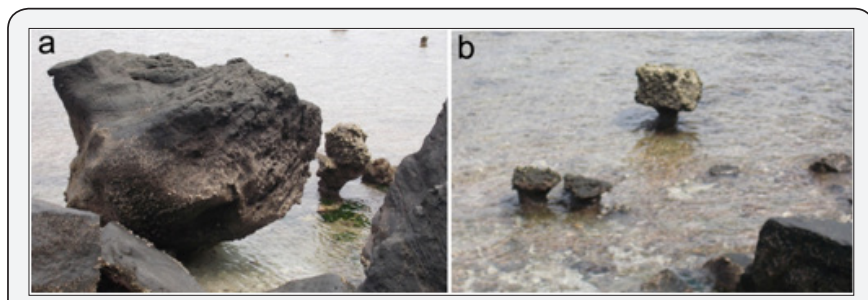

Figure 49 : Rock-cut platform and under-cut structures at about $20 \mathrm{~cm}$ above LTL at point 1 . These structures represents a former HTL now about $110-130 \mathrm{~cm}$ below present HTL, and $180-200 \mathrm{~cm}$ below the $+70 \mathrm{~cm}$ HTL dated at about AD cal. 1500-1700.

The episode of downfallen blocks must post-date the age of the corals underneath; i.e., $1601 \pm 143$ cal. yrs AD. It seems likely that the block-fall was triggered by an earthquake. At many sites along the shores of the Yasawa Islands, we observed faults, fractures and collapsed block indicative of seismic activity.

At point 1, there are remains of an old rock-cut platform with under-cut blocks and pillar at an elevation of about $20 \mathrm{~cm}$ above LTL (Figure 49, Figure 50).

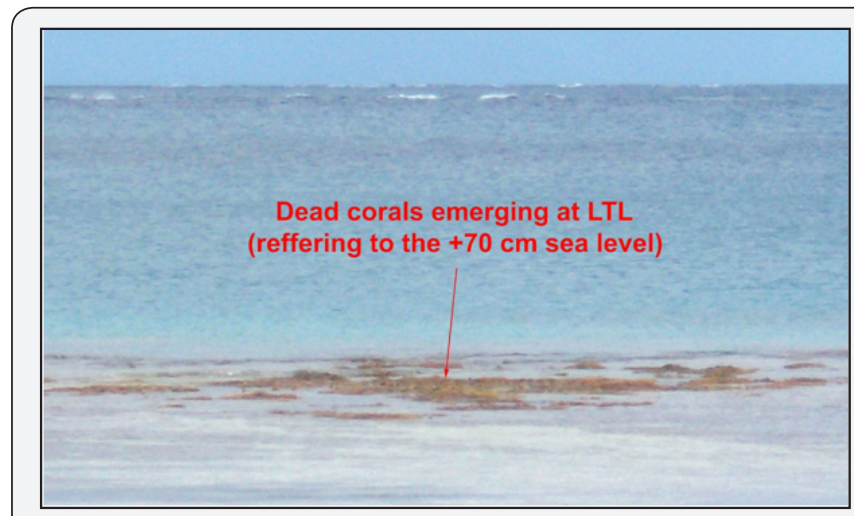

Figure 50 : At point 6 , dead corals emerge by $15 \mathrm{~cm}$ at present LTL. The corals are dead and probably represent a living colony at the time of the $+70 \mathrm{~cm}$ sea level. Available C14-dates do not support such an age, however. The surrounding area is cut into a rock-cut platform at about present LTL or shortly above (in agreement with the structures in Figure 49).

The low sea level following the $+70 \mathrm{~cm}$ high level at about 1500-1700, also trimmed the coral reef and littoral deposits off White Sandy Beach (point 6 in Figure 45) into a rock-cut platform to just above present LTL, with some coral remains emerging $15 \mathrm{~cm}$ above LTL (Figure 50). A sample from a dead coral now at $+15 \mathrm{~cm}$ above LTL was C14-dated at $388 \pm 23 \mathrm{BP}$ or AD cal. $1901 \pm 29$. Another sample $15 \mathrm{~cm}$ below LTL (Figure 51 ) was $\mathrm{C} 14$ dated at $\mathrm{AD}<1955(107.0 \pm 0.3 \mathrm{pmC})$. This implies that the dead corals at present LTL are only about 100 and 50 years old, respectively. This seems surprisingly young with respect to the fact that the corals need a minimum depth of $40-60 \mathrm{~cm}$. This would fit well with the $+70 \mathrm{~cm}$ sea level. The C14-dates are younger, however. Because present day contamination could not be excluded, a second sample of the $-15 \mathrm{~cm}$ coral was dated. The date $105.1 \pm 0.7 \mathrm{pmC}$ confirmed the recent date, however. This calls for a corresponding sea level, at least, $25 \mathrm{~cm}$ higher than today when the coral lived (Figure 51).

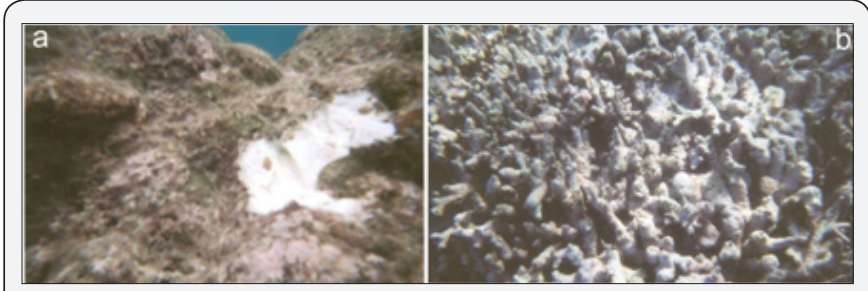

Figure 51 : The dead coral reef at White Sandy Beach (point 6). The solid top surface in "a" lies $15 \mathrm{~cm}$ below present LTL. It was sampled for C14-daing (white surface). Age: <1955cal. $A D$, which is questionably young as coral growth needs a waterdepth of about $60 \mathrm{~cm}$ below LTL, and we hardly can have a $40 \mathrm{~cm}$ drop in sea level in modern time.

The rock-cut platform at present LTL is likely to have been cut at a former HTL when sea level was $110-130 \mathrm{~cm}$ lower than today. The edge of the dead coral reef is steep, erosive and rapidly falls off to several meters depth. Coral rubble covers the trenches and sea floor outside (Figure 52). This is indicative of erosion at a former lower sea level. Despite available C14-dates, it seems reasonable that this low level occurred in the 18th century.

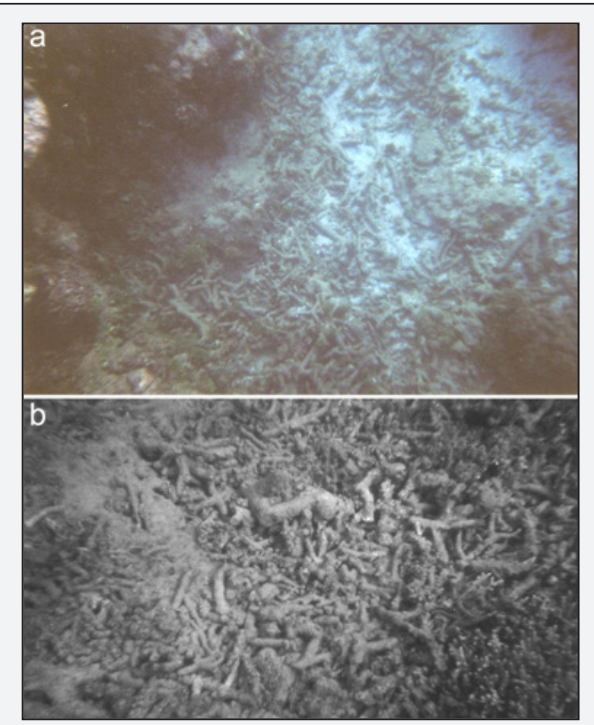

Figure 52:(a) Coral rubble fragments on the sea floor $3-4 \mathrm{~m}$ below LTL. (b) Coral rubble accumulated in a channel in the reef. Both figures indicative of severe reef erosion at a former lower sea level.

The main reef body consists of dead corals (Figure 50). Today, it also contains some living corals at depths exceeding $50 \mathrm{~cm}$ below present LTL. We also observed a number of corals grown into microatolls (Figure 53). The depth at LTL to the surface of the microatoll was measured at $40 \mathrm{~cm}$ (Figure 50). Samples from the centre of dead corals in two microatolls were C14-dated as $<1955 \mathrm{AD}(105.4 \pm 0.3 \mathrm{pmC}$ and $106 \pm 0.3 \mathrm{pmC})$. This implies that the coral centra died within the last 60 years, and that the microatoll growth is less than 60 years old and has occurred under stable sea level conditions. 


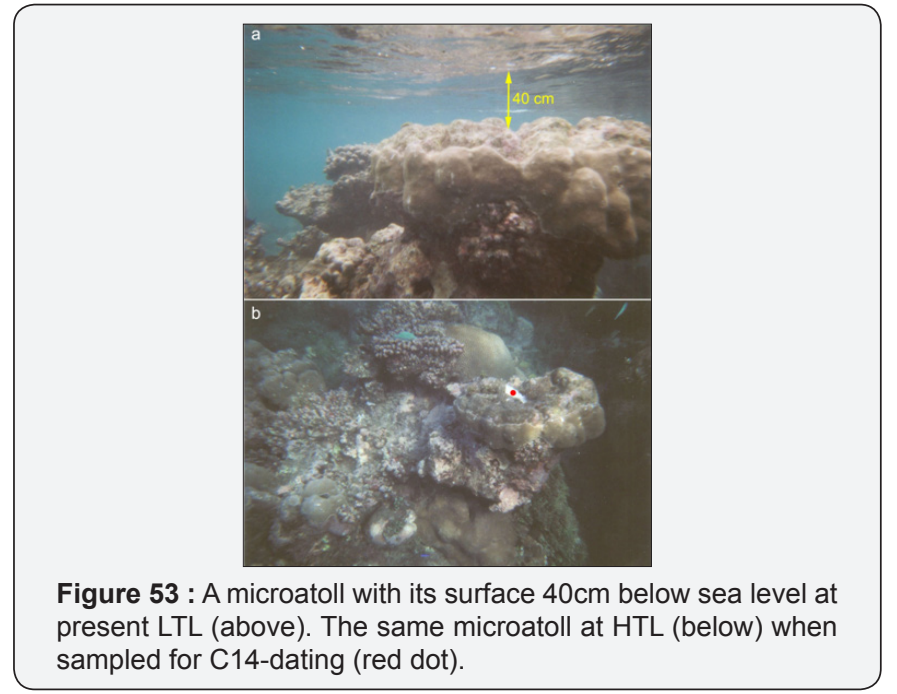

The death of the corals may be due to a sea level lowering or a severe coral bleaching episode (like the one in 1998). The re-establishment of new corals, and the sea level forcing some of them to grow into microatolls (Figure 53) is indicative of stable sea level conditions for, at least, the last 15-20 years.

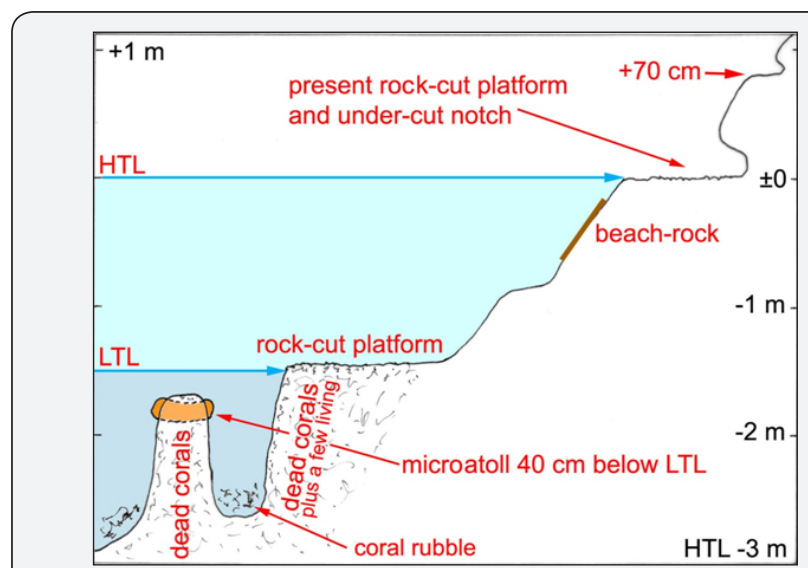

Figure 54: Summary of sea level records from White Sandy Beach [42].

Figure 53, [42] summarises the records of latest Holocene sea level changes at White Sandy Beach:

I. A $+70 \mathrm{~cm}$ dated at about AD 1500-1700.

II. A low sea level in the 18 th century its HTL $20 \mathrm{~cm}$ above present LTL, and

Table 1: Radiocarbon dating (AMS) of marine samples from Yasawa Islands and Viti Levu, 2017, at Uppsala Dating Laboratory (Ua). Marine calibration according to OxCal v4.2.4, with a reservoir effect of $450 \pm 30$ years applied.

\begin{tabular}{|c|c|c|c|c|c|c|c|}
\hline Sample & No & Site & Material & C13 & C14 Age BP & Calibrated age in BP & Calibrated Age in AD/BC \\
\hline Ua-55808 & 1 & Naisisili & shells & 1.9 & $532 \pm 23$ & $166-4$ or $86 \pm 82$ & $1784-1946$ or $1866 \pm 82$ \\
\hline Ua-55809 & 2 & Nabua & shells & 1.9 & $1799 \pm 24$ & $2600-2402$ or $2501 \pm 101$ & $551 \pm 101 \mathrm{BC}$ \\
\hline Ua-55810 & 3 & Bukama & shells & 1.8 & $1843 \pm 24$ & $1421-1257$ or $1339 \pm 82$ & $529-693$ or $611 \pm 82$ \\
\hline Ua-55811 & 4 & Nanuya & coral & -3.4 & $106.1 \pm 0.3 \mathrm{pmC}$ & $<1950$ & $<1955$ \\
\hline Ua-56629 & 5 & Navutu & shells & 4.3 & $4331 \pm 60$ & $6659-4299$ or $4479 \pm 180$ & $2529 \pm 180 \mathrm{BC}$ \\
\hline
\end{tabular}


Oceanography \& Fisheries Open access Journal

\begin{tabular}{|c|c|c|c|c|c|c|c|}
\hline Ua-55812 & 7 & Goat Is. & coral & 0.2 & $106.4 \pm 0.3 \mathrm{pmC}$ & $<1950$ & $<1955$ \\
\hline Ua-55813 & 8 & Goat Is. & coral & 0.9 & $815 \pm 24$ & $420-277$ or $420 \pm 143$ & $1530-1673$ or $1601 \pm 143$ \\
\hline Ua-55814 & 9 & Gunu & shells & 2.4 & $434 \pm 23$ & $79-0$ or $40 \pm 40$ & $1871-1950$ or $1910 \pm 40$ \\
\hline Ua-55815 & 10 & White SB & coral & -2.1 & $388 \pm 23$ & $58-0$ or $29 \pm 29$ & $1892-1950$ or $1911 \pm 29$ \\
\hline Ua-55816 & 11 & White SB & coral & -2.1 & $105.4 \pm 0.3 p m C$ & $<1950$ & $<1955$ \\
\hline Ua-55817 & 12 & White SB & coral & -1.9 & $107.0 \pm 0.3 p m C$ & $<1950$ & $<1955$ \\
\hline Ua-56628 & 12 & White SB & coral & -2.4 & $105.1 \pm 0.7 \mathrm{pmC}$ & $<1950$ & $<1955$ \\
\hline Ua-55818 & 13 & White SB & coral & -1.6 & $106.0 \pm 0.3 \mathrm{pmC}$ & $<1950$ & $<1955$ \\
\hline Ua-55819 & 15 & White SB & coral & 1.1 & $847 \pm 24$ & $445-304$ or $000 \pm 71$ & $1505-1646$ or $1576 \pm 71$ \\
\hline Ua-55820 & 16 & White SB & coral & -0.4 & $3030 \pm 25$ & $2847-2683$ or $2765 \pm 82$ & $815 \pm 82$ BC \\
\hline Ua-55821 & 17 & Maui & coral & 0.1 & $4005 \pm 26$ & $4122-3916$ or $4019 \pm 103$ & $2069 \pm 103 \mathrm{BC}$ \\
\hline Ua-55822 & 19 & Maui & coral & -9.5 & $4244 \pm 26$ & $4445-4245$ or $4345 \pm 100$ & $2395 \pm 100$ BC \\
\hline
\end{tabular}

\section{The mode of sea level changes}

The sea level change may follow main long-term trend as suggested by Nunn \& Peltier (16), or occur in an oscillatory trend (like observed in the Maldives by [44], and in Goa, India, by [42]). When evaluating and systemising the field observations, one should start from scratch and try to build up the most accurate interpretation, regardless of any outside models.

\section{Evaluating and systemising the field observations}

It is well-accepted that sea level was successively rising from the Last Glaciation Maximum low level at about 24ka ago. By about 5500 sea level had reached the present position (Figure 4). Minor sea level peaks seem to have occurred at $5300(+0.30-$ $0.45 \mathrm{~m}), 4100( \pm 0.0 \mathrm{~m})$ and $3350(+0.30 \mathrm{~m})$ cal.yrs BP (Figure 4$)$.

Our records include five sites of pre-historical sea level changes. The Maui Bay site (p. 5-6) records a former sea level position at about $\pm 0.0 \mathrm{~m}$, dated at about $4182 \pm 163 \mathrm{cal}$. BP. This seems to represent a minor sea level peak (Figure 4). This is in good agreement with the Avea Island date of $4178 \pm 180$ cal.yrs $\mathrm{BP}$ and in reasonable agreement with the age of the elevated shoreline by [7] on the Vanuabalavu Islands (above). The beachrock at Navutu Star was C14 dated at $4479 \pm 180$ cal.yrs BP (p. 11). This age is close to the age of the beachrock at Maui Bay on Viti Levu of $4345 \pm 100$ cal.yrs BP. At White Sandy Beach and Nabua there are beachrock deposits dated at $2765 \pm 82$ cal.yrs BP, and $2501 \pm 101$ cal.yrs BP, respectively. Both dates are indicative of a sea level at or shortly below the present level in the period 2500-2750cal.yrs BP, which fits well with a sea level at about $-0.5 \mathrm{~m}$ as given in Figure 4. At Bukama, there is a beachrock dated at $1339 \pm 82$ cal.yrs BP (AD cal. $611 \pm 82$ ). It implies that sea level was at about its present position or shortly below at that time. It seems to have been followed by a regression, judging from the chronostratigraphy of the Qaranilaca Cave on Vanuabalavu Island [35] dating a habitation layer at about present sea level at $\mathrm{AD}$ cal. 660-1160. In Figure 56, the dates of the beachrock deposits are plotted with respect to the graph of proposed sea level changes. They all represent periods when sea level was slightly below present sea level. The former shores 1 and 2 at Gunu Village (Figure 43) are likely to represent the 5300 and 3350cal.yrs BP sea level peaks in Figure 56.

Our main sea level story from Yasawa Islands refers to the last 500 years, including

a. A $+70 \mathrm{~cm}$ higher sea level dated at the $16 \mathrm{th}$ and $17 \mathrm{th}$ centuries,

b. A sea level lowering in the 18 th century by about 180 $200 \mathrm{~cm}$ (i.e., at $-110-130 \mathrm{~cm}$ ),

c. A sea level rise to about its present position during the last 200 years,

d. Some coral environmental changes in the last 60 years, and

e. Quite stable sea level in the last 15-20 years (with formation of microatolls).

The $+70 \mathrm{~cm}$ level is defined with high precision on Goat Island (Figure 39) and at White Sandy Beach (Figure 46). At Goat Island, we have a date of 1530-1673, and at White Sandy Beach of 1501-1646. At Bukama (Figure 20 \& 21), there is an old undercut notch at $+70 \mathrm{~cm}$. At Maui Bay (Figure 10) sand unit II goes $90 \mathrm{~cm}$ higher than the corresponding sand unit of the present beach. At Nabula, Yageta, Gunu, White sandy Beach and others sites observed from the sea, we noted littoral deposits at a former higher level, estimated between +0.5 and $+1.0 \mathrm{~m}$.

The subsequent regression is well documented at White Sandy Beach in a rock-cut platform (Figure 50) and under-cut rocks (Figure 49 ) now about $20 \mathrm{~cm}$ above the LTL. At Naisisili, there is a similar rock-cut platform $20-30 \mathrm{~cm}$ above present LTL and very prominent under-cut notches (Figures 28-30), located $100 \mathrm{~cm}$ below present HTL (Figure 26). Obviously, it is correlating to the layer in the Qaranilaca Cave section, which according to [7] represents a significant regression at about 300BP or with our calibration ADcal. 1788 \pm 114 (above).

The subsequent sea level rise brought sea level up to about its present position. At Naisisili there is a $155 \mathrm{~m}$ long shore spur, which we leveled in details (Figure 25). The building out of the spur is continual for about 150 years (dated at ADcal. $1866 \pm 82$ 
at the beginning of the spur). The crest is about $30 \mathrm{~cm}$ higher in the first part. This might suggest a somewhat higher sea level at the beginning. This might perhaps be relevant in view of the uppermost marine layer in the Qaranilaca Cave section located $0.25-0.30 \mathrm{~cm}$ above the present HTL (above). At Gunu Village, there is a double shore spur (Figure $43 \& 44$ ), built out in quite stable coastal conditions, with a date from the inner spur of $\mathrm{AD}$ cal. $1910 \pm 40$.

Microatolls were recorded and sampled at Nanuya Lailai, Goat Island (Figure 41 \& 42) and White Sandy Beach (Figure 53). They were sampled in their dead centre. The C 14-dates are all too young to be dated; i.e., <1955AD. This implies that the corals died in the last 60 years due to a sea level lowering or an extensive coral bleaching episode. A $15-20 \mathrm{~cm}$ sea level lowering might perhaps be recorded in the Kings Wharf old tide-gauge in the late 1970s [11]. It may be significant that at Denarau (Figure 9) we recorded a $10-20 \mathrm{~cm}$ sea level lowering in sub-recent time. A major coral bleaching episode occurred at the ENSO event in 1998, and it might, at least theoretically, have generated extensive coral death, too. The present growing microatolls with their surfaces $40 \mathrm{~cm}$ below present LTL indicate quite stable sea level conditions during the last 15-20 years. This is also indicated by several under-cut notches and rock-cut platforms that exhibit stable morphological conditions.

\section{Summary}

The data are combined and summarized in a general sea level curve of the last 7000 years (Figure 56) and a specific sea level curve of the last 500 years (Figure 57), which compiles our findings from the Yasawa Islands. It should be noted that the sea level changes of last 500 years have not been covered by any previous investigations (which were all confined to the Mid and Late Holocene data).

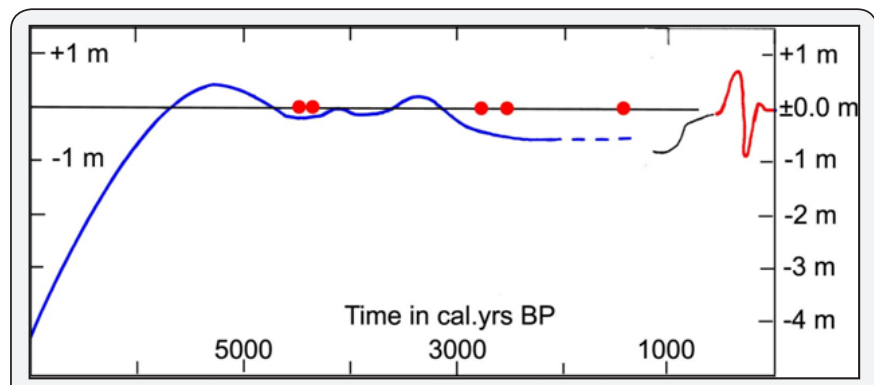

Figure 56: General sea level changes during the last 7000 cal. yrs BP as recorded in Viti Levu (blue sea level graph of Figure 4) and in Yasawa Islands (red dots representing beachrock dates and red curve giving our new sea level curve of the last 500 years, as shown in detail Figure 57).

In the graph of sea level change during the last 7000 years (Figure 56) we compare our beachrock data with the new sea level curve of Viti Levu (Figure 4). The dates from White Sandy Beach and Nabua of 2500-2975cal.yrs BP fall in the sea level low of about $-0.5 \mathrm{~m}$ in Viti Levu. The sea level regression at around 3000 cal.yrs BP exposed sandy material and led to ground water lowering, both factors of which may have led to beach-rock formation. The date from Bukama of 1340 cal.yrs BP also falls within a period where the Vitu Levu data suggest a sea level at around $-0.5 \mathrm{~m}$.

Figure 56 suggests that sea level peaked at around 5300cal. yrs BP at $+0.3 \mathrm{~m}$ or +0.45 as suggested by Ash [5] with later peats at about 4100 cal.yrs BP at $\pm 0.0 \mathrm{~m}$ and at about 3350 cal.yrs BP at $+0.3 \mathrm{~m}$. This is quite different from the graphs by $[9,10,16]$. Undoubtedly, the Fiji Islands have suffered partly episodic differential tectonics (e.g., the level of the Penultima Interglacial level on Kadavu Island, Figure 6, is indicative of uplift), and partly differential tectonics within the main island of Viti Levu (Figure 4).

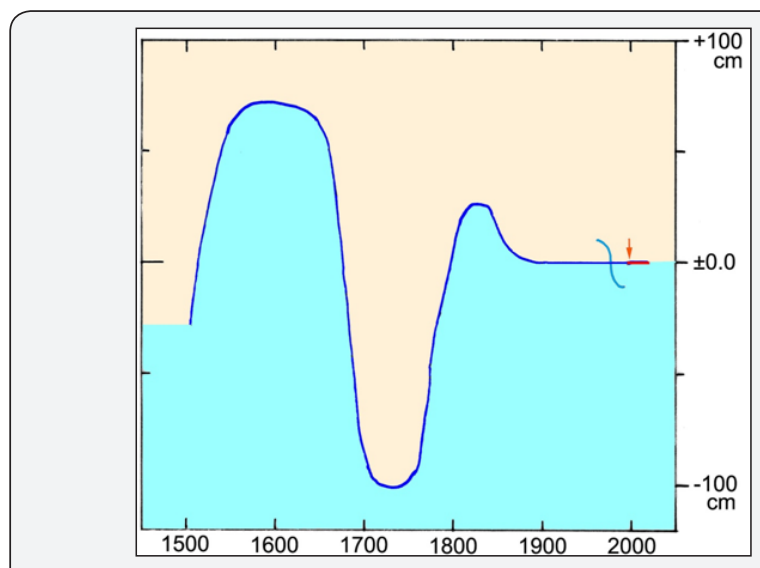

Figure 57: The new sea level curve of the last 500 years in Fiji, with special reference to Yasawa Islands. The sine symbol crossing the sea level curve at about 1975 refers to a possible sea level lowering of $10-20 \mathrm{~cm}$ affecting the coral growth. Red arrow marks the time of the 1998 ENSO event that might have caused severe coral bleaching. Red bar indicate stable sea level conditions with microatolls growing laterally instead of vertically.

Our main findings are the sea level records of the last 500 years in the Yasawa Islands (Figure 57). This curve seems to apply also for most of the others islands of the Fiji nation. We propose it as a new sea level curve of Fiji, and believe that is predominantly recording the regional changes in eustatic sea level. It is composed of 6 elements:
a. A $+70 \mathrm{~cm}$ level in the $16^{\text {th }}$ and $17^{\text {th }}$ centuries
b. A $-100 \mathrm{~cm}$ low level in the $18^{\text {th }}$ century
c. A $+30 \mathrm{~cm}$ peak in early $19^{\text {th }}$ century

d. Stable sea level condition during the last 150 years

e. Coral death in the late $20^{\text {th }}$ century, due to a $10-20 \mathrm{~cm}$ sea level lowering or maybe due to severe coral bleaching at the 1998 ENSO event

f. Quite stable sea level conditions in, at least, the last 1520 years with forced coral growth into microatolls

This implies that high sea levels are recorded at grand solar minima with Little Ice Age climatic conditions, and low sea level at the grand solar maximum in the $18^{\text {th }}$ century. This might be surprising as it is opposite to what one would expect 
from a glacial eustatic point of view. The sea level fluctuations documented (Figure 57) are very similar to those recorded in the Indian Ocean $[42,43]$, which were driven by changes in Earth's rate of rotation [45]; speeding-up during grand solar minima and slowing-down at grand solar maxima thereby forcing water masses to move in a N-S pattern $[27,46]$. Now, this process is also documented in the Fiji Islands (which came as a surprise to us). The term applied to this factor is "rotational eustasy" [27] (Table 1).

\section{Conclusion}

Our findings are condensed and summarized in Figures 56 \& 57. From 5500 to 1500 cal.yrs BP sea level seems to have oscillated between about +0.5 and $-0.5 \mathrm{~m}$, with minor peaks at $5300(+0.3$ to $0.45 \mathrm{~m}), 4100( \pm 0.0 \mathrm{~m})$ and $3350(+0.3 \mathrm{~m})$. In the last 500 years, we record high-amplitude change: high-low-highstable (Figure 57). Those changes were driven by rotational eustasy, not glacial eustasy. In the last 60 years coral reefs died due to a sea level lowering of about $10-20 \mathrm{~cm}$ or due to severe coral bleaching at the 1998 ENSO event. After that, very stable sea level conditions must have prevailed forcing corals at several sites to grow laterally into microatolls.

This documentation (Figure 57) implies that there is a total lack of signs indicating a present rise in sea level; on the contrary, our results are indicative of quite stable sea level conditions. Consequently, our records may be taken as reassurance for lowlaying coasts and islands that potential for flooding in the near future is unlikely.

\section{Acknowledgements}

We thank our friends in the Yasawa Islands, who kindly helped with permission to work in their villages areas and assisted with boat transportations: village chief Ratu Semi Rokobekalevu and Mr. Autiko Raululu and Mr. Tevita Volavola at Naisisili Village and Nabua lodge, village chief Koroli at Bukama Village, village chief Moapi Seseu and Mr. Solomoni Kikau at Yageta Village and Navutu Star resort, and village chief Wai Sate Nasau and Mrs Arieta Dugubale and Mrs Sera Drawoli Ratu at Gunu Village and White Sandy Beach lodge. We also thank Göran Possnert for rapid C14-analyses and assistance in the marine calibration. The project was made possible thanks to the kind support from The CO2 Coalition. The main content of this paper was presented at the 4th World Conference on Climate Change in Rome, Italy [43], reviewed on Word press $[47,48]$. The authors declare no conflict of interest.

\section{References}

1. MRD (2015) Plate tectonic history of Fiji. Ministry of Land and Mineral Resources.

2. MRD (2000) Earthquakes in Fiji. Mineral Resource Department of Fiji, p. 1-5.

3. ET (2017) Recent Earthquakes in Fiji.

4. Mortimer N, Hamish JC, Andy JT, Peter RK, Vaughan MS (2017) Zealandia: Earth's hidden continent. GSA Today 27(3): 27-35.
5. Ash J (1987) Holocene sea level in Northern Viti Levu, Fiji. New Zealand Journal of Geology and Geophysics 30: 431-435.

6. Kumar R, Nunn PD, Dickinson WR (2004) The Emerging Pattern of Earliest Human Settlement in Fiji: Four New Lapita Sites on Viti Levu Island. Archaeology in New Zealand 47: 108-117.

7. Nunn PD, Ollier C, Hope G, Rodda P, Omura A, et al. (2002) Late Quaternary Sea-Level and Tectonic Changes in Northeast Fiji. Marine Geology 187: 299-311.

8. Nunn PD, Omura A (1999) Penultimate Interglacial emerged reef around Kadavu Island, Southwest Pacific: implications for late Quaternary island-arc tectonics and sea level history. New Zealand Journal of Geology and Geophysics 42(2): 219-227.

9. McKoy H, Kennedy DM, Kench PS (2010) Sand cay evolution on reef platforms, Mamanuca Islands, Fiji. Marine Geology, 269(1-2): 61-73.

10. Morrison AE, Cochrane EE, Reith T, Harrocks M (2017) Archaeological and sedimentological data indicating Lapita settlement on a newly formed coastal plain: Tavu Island, Mamanuca Group, Fiji. The Holocene p.12.

11. Mörner, NA, Matlack-Klein, P (2017) The Fiji tide-gauge stations International Journal of Geosciences 8: 536-544.

12. Berryman K (1979) Seismotectonic zoning of the Fiji Islands. New Zealand Geological Survey, Report 70.

13. Nunn PD (1987) Late Cenozoic tectonic history of Lau Ridge, SouthWest Pacific, and associated shoreline displacements: review and analysis. New Zealand Journal of Geology and Geophysics 30: 241-260.

14. Nunn PD (1990) Coastal processes and landforms of Fiji: Their bearing on Holocene sea-level changes in the South and West Pacific. Journal of Coastal Research 6(2): 279-310.

15. Nunn PD (1995) Holocene tectonic histories for five islands in the south-central Lau group, South Pacific. The Holocene 5(2): 160-171.

16. Nunn PD, Peltier WR (2001) Far-field test of the ICE-4G model of global isostatic response to deglaciation using empirical and theoretical Holocene sea-level reconstructions for the Fiji Islands, southwestern Pacific. Quaternary Research 55(2): 203-214.

17. Petchey F, Anderson A, Zondervan A, Ulm S, Hogg A (2008) New marine or values for the South Pacific subtropical gyre region. Radiocarbon 50(3): 373-397.

18. Ramsey CB (2009) Bayesian analysis of radiocarbon dates. Radiocarbon 51(1): 337-360.

19. Klein J, Lerman JC, Damon PE, Ralph EK (1982) Calibration of radiocarbon dates. Radiocarbon 24: 103-150.

20. CALIB (2002) Nunn et al. used the online calibration of the CALIB 4.3 marine curve.

21. NOAA (2009) Tides \& Currents. Station 1910000 Suva.

22. Aus AID (2003) Pacific Country Report on Sea Level \& Climate: Their Present State. National Tidal Facility Australia 1-20.

23. Mörner NA (2010) Some problems in the reconstruction of mean sea level and its changes with time. Quaternary International 221: 3-8.

24. Tide-Forecast (2017).

25. NOAA (2017) Tides \& Currents, Tide Predictions at 1910000 Suva, Fijji.

26. Mörner, NA, Matlack-Klein, P (2017) The Fiji New Sea Level Project.

27. Mörner NA (2017) Our Oceans - Our Future: New evidence-based sea level records from the Fiji Islands for the last 500 years indicating rotational eustasy and absence of a present rise in sea level. International Journal of Earth \& Environmental Sciences 2(137): 1-5.

28. Lal KK, Nunn PD (2011) Holocene sea levels and coastal changes, 
southwest Viti Levu, Fiji. Australian Geographer 42(1): 41-51.

29. Nunn PD, Petchey F (2013) Bayesian re-evaluation of Lapita settlement in Fiji: radiocarbon analysis of the Lapita occupation at Bourewa and nearby sites on the Rove Peninsula, Viti Levu Island. Journal of Pacific Archaeology 4(2): 21-34.

30. Mörner NA (1996) Sea level variability. Z. Geomorphologie, NS 102: 223-232.

31. Bloom AL (1980) Late Quaternary sea level changes on South Pacific coasts: A study in tectonic diversity. In: NA Mörner, (Eds.), Earth Rheology, Isostasy and Eustasy. Wiley \& Sons, USA, pp. 505-516.

32. Nunn PD (2007) Climate, environment and society in the Pacific during the last millennium. Development in Earth and Environmental Sciences 6:1-302.

33. Sheppard PJ, Chiu S, Walter R (2015) Re-dating Lapita movements into remote Oceania. Journal of Pacific Archaeology 6(1): 26-36.

34. Nunn PD (2000) Significance of emerged Holocene corals around Ovalau and Moturiki islands, Fiji, southwest Pacific. Marine Geology 163(1-4): 345-351.

35. Thomas FR, Nunn PD, Osborne T, Kumar R, Areki F, et al. (2004) Recent archaeological findings at Qaranilaca Cave, Vanuabalavu Island, Fiji. Archaeol Oceania 39(1): 42-49.

36. Nunn PD, Matararaba S, Ramos R (2000) Investigations of anthropogenic sediments in Qaranilaca, Vavuabalavu Island, Fiji. Archaeology in New Zealand 43(1): 73-79.

37. UN (2017) Our Oceans, Our Future. UN Conference hosted by the governments of Fiji and Sweden.

38. Climate Change (2017) COP, United Nations.

39. Ash W, Ash J (1985) Holocene marine deposits on the south coast of Viti Levu, Fiji. New Zealand Journal of Geology and Geophysics 28: 571573.
40. Sugimura A, Matsushima Y, Matsumoto E, Maeda Y, Berryman K, et al. (1983) Holocene marine deposits in south coast of Viti Levu, Fiji. International Symposium on coastal evolution in the Holocene, Tokyo, Japan, pp. 123-126.

41. Mörner, NA, Matlack-Klein, P (2017) Coastal erosion in Yasawa Islands, Fiji. Natural Science 9(5): 136-142.

42. Mörner NA (2017) Coastal morphology and sea-level changes in Goa, India, during the last 500 years. Journal of Coastal Research 33(2): 421-434.

43. Mörner, NA, Matlack-Klein, P, Soon, W (2017) Our Oceans - Our Future: New evidence-based sea level records from the Fiji Islands indicating no rise in ocean level. $4^{\text {th }}$ World Conference on Climate Change, October 19-21, Rome, Italy, Abstracts, Journal of Earth Science \& Climate Change 8(10): 64.

44. Mörner NA (2007) Sea level changes and tsunamis, environmental stress and migration overseas. The case of the Maldives and Sri Lanka. Internationales Asienforum 38: 353-374.

45. Mörner NA (2010) Solar minima, Earth's rotation and Little Ice Ages in the past and the future. The North Atlantic-European case. Global Planetary Change 72(4): 282-293.

46. Mörner NA (2015) Multiple planetary influence on the Earth. In: Mörner NA (Ed.), Planetary Influence on the Sun and the Earth. Modern Book-Burning, Nova Sci Publ pp. 39-50,

47. Wordpress (2017) Fear Not For Fiji.

48. https://tallbloke.wordpress.com/2017/10/24/wcc4-romeinterview-with-nils-axel-morner/

\section{Your next submission with Juniper Publishers will reach you the below assets}

- Quality Editorial service

- Swift Peer Review

- Reprints availability

- E-prints Service

- Manuscript Podcast for convenient understanding

- Global attainment for your research

- Manuscript accessibility in different formats

( Pdf, E-pub, Full Text, Audio)

- Unceasing customer service

Track the below URL for one-step submission https://juniperpublishers.com/online-submission.php 